\title{
Pink salmon in Norway: the reluctant invader
}

\author{
Odd Terje Sandlund $\mathbb{D} \cdot$ Henrik Hårdensson Berntsen • Peder Fiske • \\ Jorma Kuusela $\cdot$ Rune Muladal • Eero Niemelä • Ingebrigt Uglem • \\ Torbjørn Forseth · Tor Atle Mo • Eva B. Thorstad • Alexey E. Veselov • \\ Knut Wiik Vollset $\cdot$ Alexander V. Zubchenko
}

Received: 5 July 2018/Accepted: 16 December 2018/Published online: 22 December 2018

(C) The Author(s) 2018

\begin{abstract}
In 2017, Norway experienced an invasion of the Pacific salmonid pink salmon (Oncorhynchus gorbuscha) in numbers never before seen in rivers all along the coast. Significant numbers were also caught in other parts of northwestern Europe. Pink salmon has been observed in variable numbers in Norwegian waters in the summer and autumn of most years since 1960, after the first successful Russian introduction of pink salmon fry in rivers draining to the White Sea in northwest Russia in 1959. With the exception of 1960 ,
\end{abstract}

Electronic supplementary material The online version of this article (https://doi.org/10.1007/s10530-018-1904-z) contains supplementary material, which is available to authorized users.

O. T. Sandlund $(\bowtie) \cdot H$. H. Berntsen .

P. Fiske · I. Uglem · T. Forseth · E. B. Thorstad

Norwegian Institute for Nature Research (NINA), PO Box 5685, Torgarden, 7485 Trondheim, Norway

e-mail: odd.sandlund@nina.no

R. Muladal

Naturtjenester i nord AS, Holtvegen 66, 9016 Tromsø,

Norway

J. Kuusela · E. Niemelä

Natural Resources Institute Finland (LUKE), River Teno

Research Station, Nuorgamintie 7, 99980 Utsjoki, Finland

Present Address:

E. Niemelä

Statens hus, Damsveien 1, 9815 Vadsø, Norway pink salmon have been most abundant in odd years, based on the odd-year broodline of the 2-year life salmonid. Even-year fish has generally been less abundant, but in recent years, significant numbers of this broodline have also been caught. In this paper we review the available information on pink salmon in Norwegian rivers and discuss (1) to what extent the presence of this species in Norway has been driven by Russian introductions and natural reproduction in Russian, and lately in Norwegian, rivers, and (2) the likelihood of reproducing populations of pink salmon being established in more Norwegian rivers. Considering the continued propagule pressure in terms of adult pink salmon entering and spawning in

\author{
T. A. Mo \\ NINA, Gaustadalléen 21, 0349 Oslo, Norway
}

A. E. Veselov

Institute of Biology, Karelian Scientific Center, Russian Academy of Sciences, Petrozavodsk, Russia 185035

K. W. Vollset

Uni Research Environment, Nygårdsgaten 112,

5008 Bergen, Norway

A. V. Zubchenko

Knipovich Polar Research Institute of Marine Fisheries and Oceanography (PINRO), Murmansk, Russia 
Norwegian rivers, it is puzzling that self-propagating populations apparently only have been established in some rivers in the northernmost part of the country. The potential impact of pink salmon on native salmonids and river ecosystems is discussed briefly. Extensive research is required to understand the mechanisms that determine the fate of pink salmon as an alien species, and specifically the possible impact of pink salmon on native salmonids and the environment in the recipient rivers and in the ocean.

Keywords Pink salmon - Invasive species - Atlantic salmon $\cdot$ Competitive interactions $\cdot$ Migration timing

\section{Introduction}

The introduction of non-native species is considered one of the major threats to native biodiversity and ecosystem services (Rahel 2002; Pejchar and Mooney 2009). Introductions happen when species are moved outside of their natural range by humans (FalkPetersen et al. 2006). This may happen accidentally, or with the goal of establishing new populations. Purposeful introductions are commonly motivated by economy, subsistence or recreation, and have occurred throughout human history. Most groups of organisms have been involved, including mammals, fishes, birds, reptiles, amphibians, invertebrates and plants (Olden et al. 2011). There are some well-documented examples among salmonid fishes which have been spread over most of the world, such as brown trout (Salmo trutta) (MacCrimmon and Marshall 1968), and several Oncorhynchus species (Crawford and Muir 2008).

Most introductions fail to establish self-reproducing populations (Williamson 1996). In most cases, the released individuals perish, or they survive but do not manage to reproduce. In some cases, reproduction may succeed for one or two generations, before the temporary occurrence disappears (Simberloff and Gibbons 2004). Even if reproduction does succeed, the established population may remain at a low, almost undetected, level for a long time. In some cases, the sparse population may suddenly increase and start secondary spreading, and occasionally the introduced species establishes directly and increases in numbers, soon to dominate the recipient ecosystem (Fausch 2008). The abundant invader population may sometimes go through a "boom-and-bust" development, with the dense population crashing and settling at a moderate level of density (Simberloff and Gibbons 2004).

The impact of species introductions is associated with the ability of the established alien species to spread and establish in more localities than the original target locality. Secondary spreading is perhaps the greatest challenge for management, because it becomes impossible to contain unwanted species with a large ability to disperse.

Species of the salmonid genus Oncorhynchus have for decades been introduced to innumerable localities outside their native range (Crawford and Muir 2008). For instance, rainbow trout (O. mykiss), which is native to western North America, was first introduced in Europe in the late 1800s, and is now one of the most widely introduced fishes on a global scale, present on all continents except Antarctica (MacCrimmon 1971; Stankovic et al. 2015). Another example of a largescale and long-term introduction of Pacific salmon is the release of millions of fertilized eggs or fry of pink salmon (O. gorbuscha) from rivers on the Russian Pacific to rivers in Northwest Russia, draining to the White Sea (Bakshtansky 1980).

Pink salmon has a wide native range in the northern Pacific. On the North American side, it previously occured in rivers from the Sacramento River, California $\left(38^{\circ} \mathrm{N}\right.$ latitude) to and around the northern tip of Alaska $\left(71^{\circ} \mathrm{N}\right)$. In rivers on the Eurasian continent, it has been recorded from Korea $\left(37^{\circ} \mathrm{N}\right)$ to the river Lena in Siberia $\left(73^{\circ} \mathrm{N}\right)$ (Heard 1991). However, the most abundant populations are found in the northern part of this area (from Alaska to Puget Sound $\left(48^{\circ} \mathrm{N}\right)$ and from Siberia to southern Sakhalin $\left(40^{\circ} \mathrm{N}\right)$; Ruggerone and Irvine 2018). It appears that the abundance and the number of populations decrease in the south, while the northern distribution is expanding (Radchenko et al. 2018).

The history and results of the introduction of pink salmon in Russian waters have been relatively well documented, in Russian as well as in English (Dushkina 1994; Chereshnev et al. 2002; Zubchenko et al. 2010). The early secondary spreading and possible establishment of this species in Norwegian waters were also documented (Berg 1961, 1977; Bjerknes and Vaag 1980). Since the first observations in Norway in 1960, pink salmon has been an irregular element in Norwegian fauna. In some rivers in the 
northernmost part of the country (around $70^{\circ} \mathrm{N}$ ), pink salmon have been observed in most years, although in widely varying numbers (Berg 1977; Niemelä et al. 2016). Further south, numbers have in most years been low. However, in 2017, pink salmon were observed in rivers along the entire coastline, and in high numbers in many rivers (Mo et al. 2018). In 2017, pink salmon was also caught in rivers in the UK and Ireland, in countries in mainland western Europe, as well as in Iceland and on the east coast of Canada (Bartlett 2017; BBC 2017; Whelan 2017; Armstrong et al. 2018).

Here we provide a review of the ecological characteristics of pink salmon and its secondary spreading to Norwegian waters after the transplantation to rivers in north-western Russia. We describe the complicated history of pink salmon in Norway and discuss the various factors that may have influenced the observed development, and the potential for future establishment. The aim is to understand the dynamics of this unusual case of secondary spreading of a potentially invasive species. Interactions between pink salmon and Atlantic salmonids in rivers are little known, but the extent of potential impacts is substantial, considering that, along the Norwegian coast from the border to Russia in the northeast to the border to Sweden in the southeast, there are approx. 450 rivers with anadromous Atlantic salmon (Salmo salar), more than 1000 rivers with anadromous brown trout, and, in the three northernmost counties, more than 100 rivers with anadromous Arctic charr (Salvelinus alpinus). The extent of possible interactions in the marine environment is also unknown, but in the Pacific, abundant pink salmon are considered a serious competitor with other Oncorhynchus species (Ruggerone and Nielsen 2004).

\section{Life cycle of pink salmon}

Among the anadromous salmonids, pink (or humpback) salmon is one of the species with the most restricted residence time in freshwater. The adults enter the river a short time before spawning and they survive only a few weeks after spawning before they all die. All fry leave the river shortly after commencing external feeding (Heard 1991; Quinn 2005).

Pink salmon almost invariably has a 2-year life cycle. The adult fish enter the river to spawn during June-September, depending on location. Spawning occurs between mid-July and late October (Scott and
Crossman 1973; Dyagilev and Markevich 1979; Heard 1991; Zubchenko et al. 2004). Each female carries 1200-1900 eggs (Heard 1991). She digs nests in the gravel in the river bed, and the fertilized eggs hatch into alevins with large yolk sacs during winter or early spring. The fry emerge from the gravel in March-May, when they are approx. $30 \mathrm{~mm}$ in length, and the yolk sac has been absorbed. Already at this stage, the fry are saltwater tolerant (Gallagher et al. 2013) and downstream movement appears to start almost immediately. The time needed to reach the estuary is generally determined by the distance from the spawning ground. Pink salmon commonly spawn in the lower $50 \mathrm{~km}$ of the rivers, but in large rivers, spawning may be as much as hundreds of $\mathrm{km}$ upstream (Ishida 1966; Basham and Gilbreath 1978; Chereshnev et al. 2002). Spawning may also occur within the tidal zone, particularly in short coastal streams (Heard 1991). The juveniles appear to spend a variable period, even up to a few months, in the estuaries and coastal waters before moving to sea, where they stay for one winter (Heard 1991; Moore et al. 2016). They return as age-1 adults (i.e. one sea-winter) to rivers to spawn.

The 2-year life cycle of pink salmon has resulted in the evolution of so-called odd and even-year broodlines. Fish that spawn in odd years produce offspring that will spend one winter at sea and return to spawn in odd years, while the offspring of fish that spawn in even years spawn in even years. In most rivers in the native range, both broodlines occur (Gordeeva and Salmenkova 2011). Overall, within the native range in the Pacific, the relative abundance of the two broodlines has varied among regions (Irvine et al. 2014), although the odd-year broodline has generally been most abundant. Presently, the odd-year dominance seems to increase; the changes may be associated with climate change as well as large scale stocking with hatchery produced fish (Irvine and Fukuwaka 2011; Ruggerone and Irvine 2018).

The two broodlines are reproductively isolated from each other, but still the genetic differences between them is restricted (Olsen et al. 1998; Churikov and Gharrett 2002; Hawkins et al. 2002; Tarpey et al. 2018), not exceeding the general level of inter-population differences in salmonids (Althukov et al. 2000). 
Introductions to the Russian northwest

The first introduction of pink salmon in the Russian Barents region occurred in 1956-1957. In late 1956, fertilized eggs were transported from the southern part of the island of Sakhalin $\left(48^{\circ} \mathrm{N}\right)$ to local hatcheries in the White Sea drainage $\left(64^{\circ} \mathrm{N}\right.$, Fig. 1). In the spring of 1957, 3.5 million fry were released into rivers directly after yolk sacs had been resorbed (Azbelev 1960; Azbelev et al. 1962; Bakshtansky 1970; Zubchenko et al. 2004). A similar operation was repeated with 6.2 million fry in 1957-1958, but according to records, these two stocking events produced no returning adult fish. In early 1959, the fry were therefore kept in hatcheries until they had commenced external feeding, and 15 million fry of the even-year broodline (expected to return for spawning in 1960) were released. This stocking resulted in more than 76,000 adults being caught in Russian waters in 1960 (Zubchenko et al. 2004). This cohort was also recorded in high numbers in Norwegian waters, with an estimated catch of 20-25 tonnes (Berg 1961, 1977; Rasmussen 1961). During 1960-1964, 10-36 million pink salmon fry were stocked annually in the White Sea area, but significant catches of returning adults were only recorded in 1965 (Zubchenko et al. 2004). Based on material originating in Sakhalin, variable numbers of pink salmon fry were stocked almost every year until 1979 (Zubchenko et al. 2004; Gordeeva and Salmenkova 2011). There were abundant returns of adult fish in most odd years (i.e. of the odd-year broodline). Reproduction in Russian rivers was observed in some years associated with North Atlantic warming (Karpevich et al. 1991), but the aim of establishing permanent self-sustaining populations was not reached (Gordeeva et al. 2006). The stocking programme with eggs from Sakhalin was terminated in 1979 (Gordeeva and Salmenkova 2011). It was assumed that the reason for the failure to attain natural reproduction was that the stocking material originated in rivers too far south. The timing of spawning migration and spawning in salmonids are, to a large extent, inherited traits (McGregor et al. 1998; Carlson and Seamons 2008). It has been suggested that the southern fish likely would spawn too late, so that early winter cooling might disturb the early embryo development (Gordeeva and Salmenkova 2011). Spawning at an unsuitable time may also cause poor development during incubation and hatching at an unsuitable time in spring (Markevich et al. 1978; Agapov 1986).

It should be noted that during 1960-1980, returning adult pink salmon were recorded over a large area, from the Kara Sea in the east to Iceland, Scotland, England and Denmark on the western side of the Eurasian continent (Mills 1991). In 1961, pink salmon was for the first time recorded in Spitsbergen (around $77^{\circ} \mathrm{N}$ latitude, Berg 1977), and presently the species is commonly observed in that area.

The stocking activity in northwest Russia was resumed in 1985, when eggs of odd-year pink salmon were imported from a more northern locality on the Pacific (the river Ola, Magadan oblast, nearly $60^{\circ} \mathrm{N}$ latitude) and incubated in local hatcheries. After hatching, the fry were released in the spring of 1986 , with adult fish returning in 1987. Import of eggs was repeated in 1989, with odd-year fry being released in early 1990. These introductions resulted in successful natural reproduction by odd-year pink salmon in White Sea rivers. Even-year eggs from the Magadan region were imported in 1986 and the fry released in 1987, resulting in a single return in 1988, but apparently no natural reproduction. When the import of even-year eggs was repeated in 1998, and the fry released in 1999, it resulted in a catch of 8100 adult fish in 2000, and a limited natural reproduction, with 1100 adult fish caught in 2002. Low numbers of evenyear fish have also been caught in later years. Thus, the Russian stocking programme between 1985 and 1999, based on broodstock from the Magadan region, has resulted in local self-reproducing populations in the White Sea area, with odd-year stocks being more abundant than even-year stocks. In Norway, no hatchery production of pink salmon has occurred since some very limited experiments (aiming at net pen production of fish) during the period 1963-1975 (Berg 1977). We are only aware of one occasion of pink salmon stocking in Norway, in the southern river Søgneelva $\left(58^{\circ} \mathrm{N}\right)$ in 1976 (Anon. 1978), resulting in no known recaptures. Consequently, all pink salmon caught since 2001 in the northeast Atlantic, the Arctic Sea and the Barents Sea, and in rivers draining into these seas, is the result of reproduction in the wild.

The stocking in Russian rivers has resulted in local self-reproducing populations. Catches of odd-year adult fish were usually below 100 tonnes before 2001. After 2001 catches have increased significantly, with an odd-year mean for 2001-2017 of 220.5 tonnes 
Fig. 1 Above: The geographical position of Norway, in relation to northwest Russia, with latitudes and major sites mentioned in the text. Below: Finnmark county with the position of rivers where, according to the Finnmark County Governor's office, regular spawning by pink salmon has been observed (numbers 1-12), possible spawning rivers (numbers 13-16), and the two largest rivers in the county (numbers 17-18). For geographical coordinates, catchment area and mean discharge of the rivers, see Supplementary Table S1
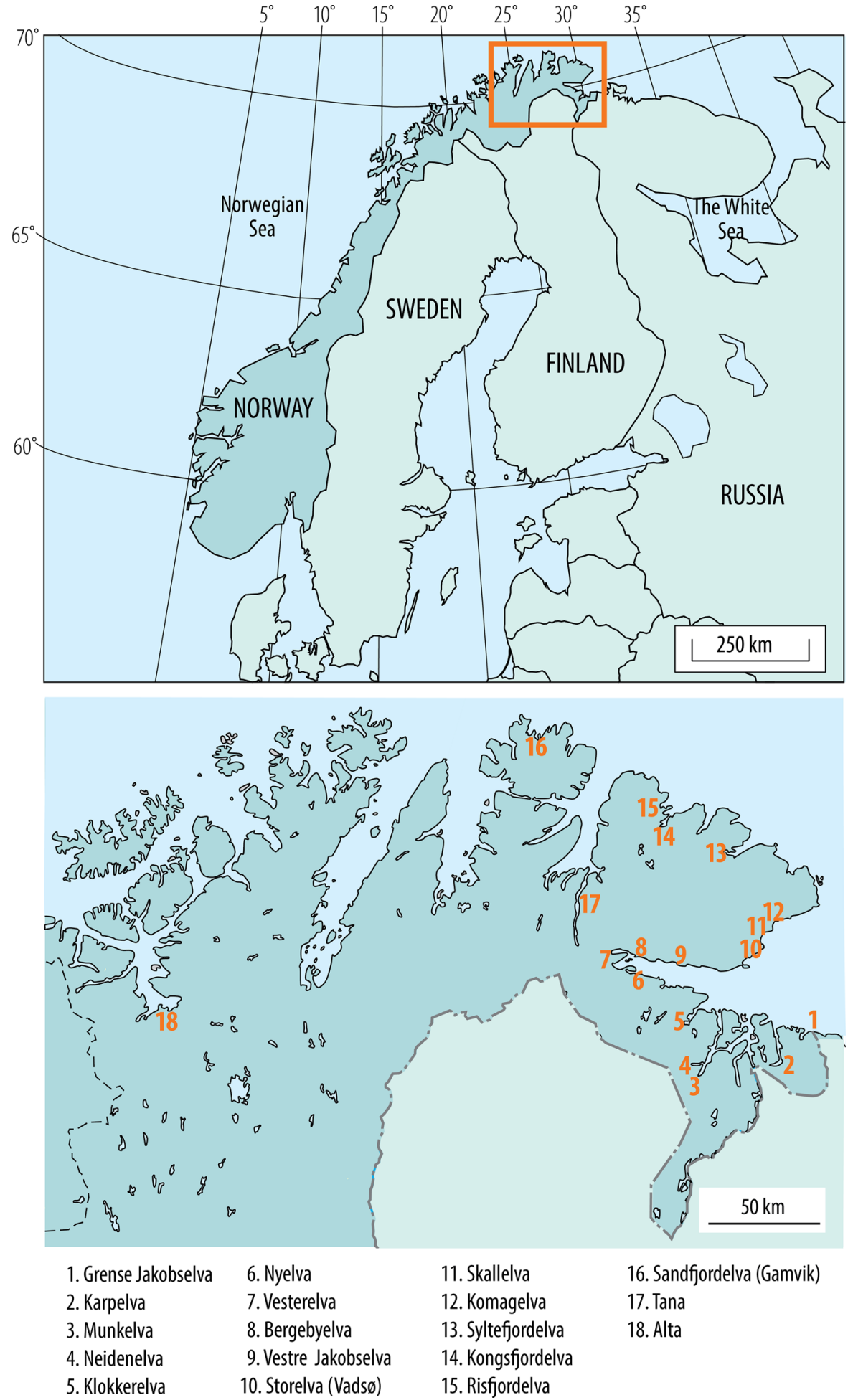
(99.5-373.4 tonnes; the highest amount in 2017). The mean weight of pink salmon in the White Sea rivers has increased from 1.3 to $1.9 \mathrm{~kg}$ over the last 11 years (A. Veselov, unpublished data). If we assume a mean weight of $1.5 \mathrm{~kg}$, the mean odd-year catch in 2001-2017 corresponds to 147,000 fish per year, with a maximum in 2017 of nearly 250,000 fish. The tremendous variation in adult returns may be due to a sub-optimal environment even for this northerly broodstock (Gordeeva and Salmenkova 2011).

In spite of the substantial decline in catches of evenyear fish since 2000, there is a variable but small catch of even-year fish in Russian rivers (between $30 \mathrm{~kg}$ and 11 tonnes). There is also a restricted, but quite regular, even-year pink salmon occurrence in Norwegian rivers. This indicates that in these non-native stocks, the even-year broodline is less productive in the wild than the odd-year broodline. According to Gordeeva et al. (2015) and Gordeeva (2017) the reason may be that, while the odd-year broodline was able to respond quickly to the severe natural selection pressure in the new environment, this was not the case with even-year fish.

\section{Secondary spreading, occurrence and establishment in Norway}

\section{History}

The first record of pink salmon in Norway was in 1960. This was apparently a result of the successful return of adult fish from the Russian stocking in the spring of 1959 (Berg 1977). This is possibly the most abundant return of even-year pink salmon ever recorded in Norwegian waters. Almost all subsequent peak years have been odd-year fish (Table 1). Comparing the catches in 1960 in Norwegian and Russian waters may also indicate quite poor homing in this group of fish. The Norwegian catch was 20-25 tonnes (Berg 1977), corresponding to approx. 13,000-17,000 fish, while that year's Russian catch was 76,300 fish (Zubchenko et al. 2004). A number of spawning fish were observed in at least 15 rivers in Finnmark, which is Norway's northernmost county (around $69^{\circ} \mathrm{N}$, Fig. 1), and pink salmon were caught as far south as Bergen $\left(60^{\circ} \mathrm{N}\right.$; Berg 1961) (Fig. 1). During 1960-1975, abundant returns to Russian waters were accompanied by relatively large catches and numerous observations in Norwegian waters (Berg 1977; Zubchenko et al. 2004).

There are no reliable time series statistics for total catches of pink salmon in Norwegian waters, neither for the sea, nor for rivers, but a summary of observations is given in Table 1 (with more details in Supplementary Table S3). However, pink salmon catches in the large river Tana (Teno in Finnish, catchment area $16,377 \mathrm{~km}^{2}, 70 \%$ in Norway, $30 \%$ in Finland, mean annual discharge $197 \mathrm{~m}^{3} \mathrm{~s}^{-1}$ ) have been recorded since 1974 (Fig. 2). No stocking of pink salmon has ever occurred in this river, but the catch statistics have included pink salmon together with Atlantic salmon and anadromous brown trout. There has been a tremendous variation in the catches of pink salmon, between zero (in 1981, 1982 and 1984) and 2.8 tonnes (in 2017) (Fig. 2). Catches of pink salmon were also unusually high in 1977 , at 2.4 tonnes, while in most years catches have been below 1 tonne. Mean pink salmon catch over the 44 years on record in the river Tana was $293 \mathrm{~kg}$. During the period from 1989 to 2007, catches were relatively high in all odd years (mean: $446 \mathrm{~kg}$ ), while most even-year catches were low (mean: $126 \mathrm{~kg}$ ), although there were relatively high catches of even-year fish in 1976 and 2000. A similar data set for the period 2007-2017, which is available for the smaller river Neidenelva (catchment area $3009 \mathrm{~km}^{2}, 8 \%$ in Norway, 92\% in Finland) mirrors the variation in Tana, with high catches of pink salmon in 2007 and 2017 (Fig. 3). The distances, as a fish may swim, from the Russian border to the estuaries of Tana and Neidenelva are approx. $235 \mathrm{~km}$ and $62 \mathrm{~km}$, respectively. No statistics are available for the river Neidenelva before 2007, but high numbers of pink salmon have regularly been observed in the river since the turn of the century $(\mathrm{K}$. Skimlied, fishery inspector, personal comm.).

Comparing the catches in the river Tana with Russian records, there were parallel, relatively high numbers in 1977 and 1979 (Fig. 2), while almost no pink salmon were reported neither in Tana nor in Russian rivers during 1980-1988. During the 1980s, however, there were some marine catches of pink salmon in Norwegian waters (Jensen et al. 2013). From 1989 until 2003, there was again a parallel variation between high odd-year and low even-year counts in Tana and in Russian rivers (Fig. 2). For the total period with overlapping catch data (1974-2003) between northwest Russia and Tana, the annual 
Table 1 Summary of pink salmon observations in Norway (more details in Supplementary Table S3)

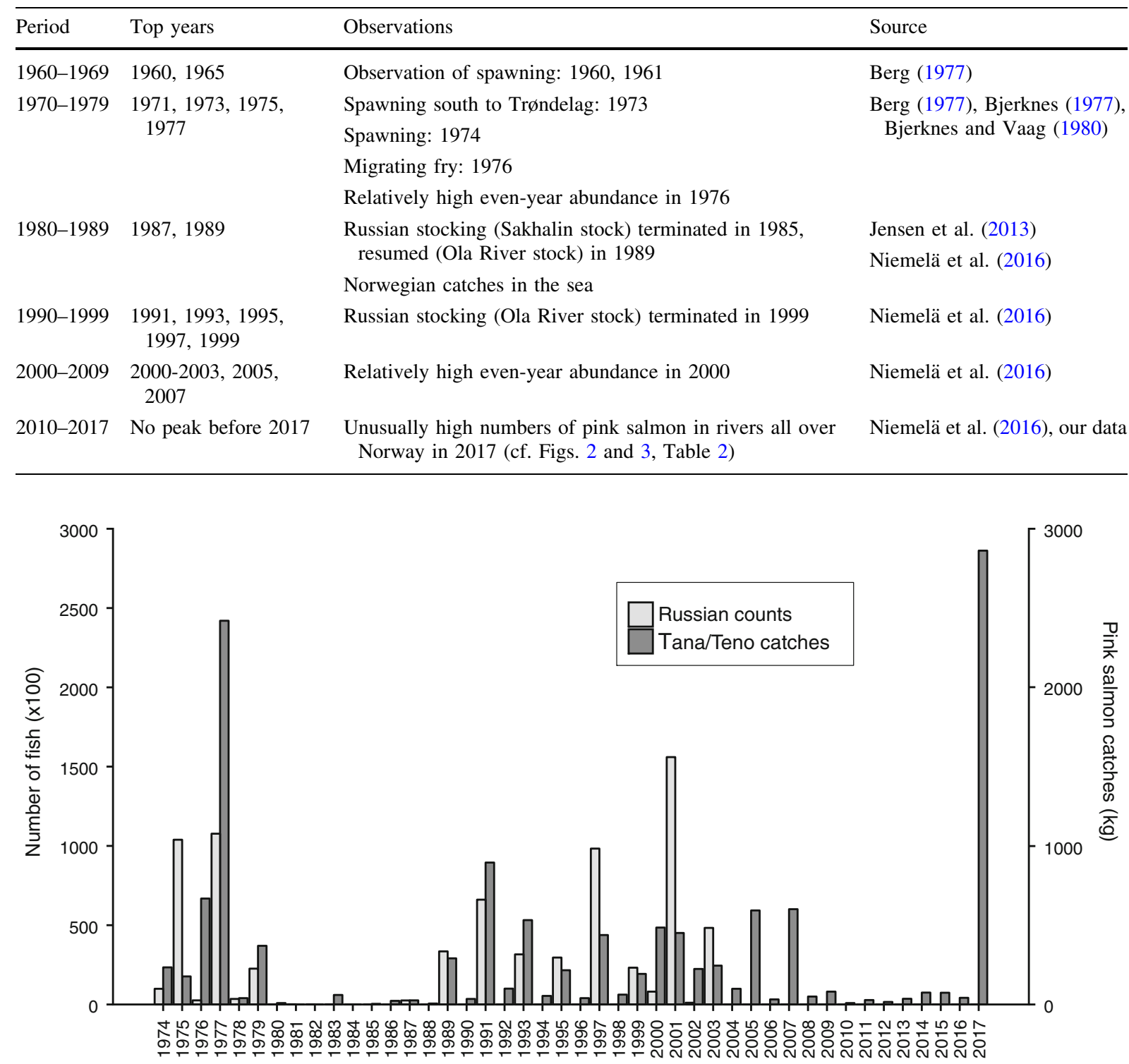

Fig. 2 Sum of recorded catches of pink salmon in the river Tana/Teno in Norwegian and Finnish waters, 1974-2017 (data from LUKE and Tanavassdragets fiskeforvaltning, www. tanafisk.no), and counts of adult pink salmon in Russian

catches were significantly, but weakly, correlated $\left(\mathrm{R}^{2}=0.2, p=0.048\right)$.

Since the turn of the century, pink salmon has been observed in high numbers in many rivers in eastern Finnmark. Because stocking of pink salmon has not occurred since 1999 in northwest Russia, and no stocking has occurred in Norway (excepting one minor attempt in the south of the country in 1976), pink catches 1974-2003 (Zubchenko et al. 2004). Hatchery-produced fish were stocked in Russian rivers at irregular intervals until 1999. No stocking of pink salmon has occurred

salmon entering rivers in this area from 2001 onwards stem from natural spawning. Rivers on the southern side of the Varangerfjord (numbers 1-7 in Fig. 1) as well as the rivers Vestre Jakobselva and Komagelva (numbers 9 and 12 in Fig. 1) have regularly received the highest number of fish. Snorkelling surveys, as well as catches, documented the occurrence of pink salmon in nine Finnmark rivers in 2007 (Muladal 


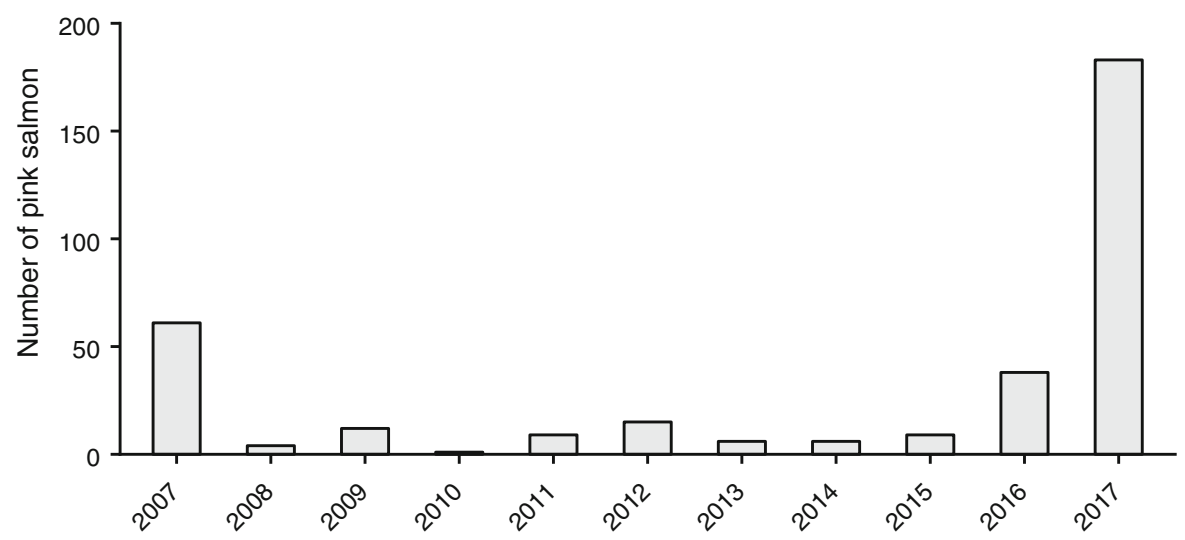

Fig. 3 Catches of pink salmon in the river Neiden, 2007-2017. Data from the Neiden fellesskap (https://www.inatur.no). No stocking of pink salmon has occurred

Table 2 Reported catches and observations of pink salmon in rivers in Norwegian counties in 2017. Observations include snorkelling surveys and video camera monitoring

\begin{tabular}{|c|c|c|c|c|c|c|c|}
\hline \multirow[t]{2}{*}{ County } & \multirow{2}{*}{$\begin{array}{l}\text { Total } \\
\text { catch }\end{array}$} & \multicolumn{2}{|l|}{ Sea } & \multicolumn{4}{|l|}{ River } \\
\hline & & Angling & $\begin{array}{l}\text { Salmon bag nets } \\
\text { and bend nets }\end{array}$ & \# rivers & Angling & $\begin{array}{l}\text { Targeted } \\
\text { removal fishing }\end{array}$ & Observations \\
\hline Finnmark & 4264 & 51 & 92 & 46 & 1954 & 2167 & 4997 \\
\hline Troms & 288 & 19 & 11 & 27 & 195 & 63 & 90 \\
\hline Nordland & 504 & 80 & 4 & 51 & 420 & - & - \\
\hline Nord-Trøndelag ${ }^{\mathrm{a}}$ & 219 & 52 & 68 & 12 & 68 & 31 & - \\
\hline Sør-Trøndelag ${ }^{a}$ & 69 & 8 & 21 & 13 & 40 & - & 98 \\
\hline Møre og Romsdal & 215 & 24 & 3 & 30 & 152 & 36 & 11 \\
\hline Sogn og Fjordane & 140 & 12 & - & 24 & 102 & 26 & 1 \\
\hline Hordaland & 370 & 22 & - & 25 & 217 & 131 & 224 \\
\hline Rogaland & 182 & 10 & 16 & 19 & 156 & - & 7 \\
\hline Vest-Agder & 30 & - & - & 6 & 30 & - & - \\
\hline Aust-Agder & 2 & - & - & 1 & 2 & - & - \\
\hline Telemark & 6 & - & - & 1 & 6 & - & - \\
\hline Vestfold & 21 & - & - & 2 & 21 & - & - \\
\hline Buskerud & 15 & 2 & - & 2 & 13 & - & - \\
\hline Oslo & 22 & - & - & 2 & 22 & - & - \\
\hline Akershus & 2 & 1 & - & 1 & 1 & - & - \\
\hline$\emptyset$ Østfold & 41 & 1 & - & 1 & 40 & - & - \\
\hline Total & 6390 & 282 & 215 & 263 & 3439 & 2454 & 5428 \\
\hline
\end{tabular}

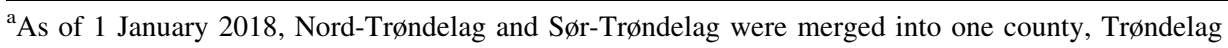

2009). Surveys in the autumn of 2011 documented pink salmon in only four of these nine rivers. In 2015 , pink salmon was caught or observed in 11 out of 16 surveyed Finnmark rivers (Muladal 2011, 2016).
Peak year 2017

There has been no organized monitoring of the occurrence of pink salmon in Norwegian rivers. However, catches have been recorded by anglers, 
who generally report unusual catches (e.g. "strangelooking" salmon). Approximately 75,000 persons per year fish for Atlantic salmon, sea trout and Arctic charr in Norwegian rivers. During recent decades (in some rivers since 1989), after-season targeted fishing has been organized to remove Atlantic salmon aquaculture escapees, also recording the presence of pink salmon (Lund et al. 1991; Fiske et al. 2006). Finally, observations of pink salmon have been made during snorkelling surveys for Atlantic salmon and brown trout spawners, which have been performed in several rivers since the 1980s (Ugedal et al. 2005; Orell and Erkinaro 2007; Muladal 2009, 2016), and from recordings by monitoring video cameras installed in numerous fishways. The numbers for 2017 are a result of a Facebook-based campaign, initiated in the beginning of July, when posts by anglers on Facebook describing catches of pink salmon had been seen. The issue was then during July brought to the attention of all parties involved in fishing, monitoring and research on anadromous salmonids, because of the unusually high numbers of pink salmon caught and observed. The Facebook campaign made it possible to organise an ad hoc reporting of catches because information could be spread fast. In addition, those responsible for wild salmon management at the county governors' offices were asked in questionnaires after the fishing season in 2015, 2016 and 2017 if they knew of any pink salmon catches. Still, the numbers reported during 2017, as well as earlier years, are likely minimum numbers.

During the last years before 2017, regular catches have been made in Finnmark County, close to the Russian border, while only the occasional individual pink salmon has been seen in other parts of the country (Fig. 4). Before 2012, pink salmon had been observed or caught in approximately 50 rivers in Norway. In 2015, 162 individuals were reported from 21 rivers, and in 2016, 159 individuals were reported from 30 rivers (Fig. 4). This is in stark contrast to 2017, when a total of 11,818 individual pink salmon were caught or observed in 263 rivers (Fig. 4, Table 2). Catches of pink salmon were reported from all the 17 Norwegian counties with a coastline. The first pink salmon catch in 2017 occurred 1 June, and the median catch date for the whole country was 26 July. In 258 rivers at least one pink salmon was caught, while in seven rivers the species was only observed during snorkelling surveys or by video cameras. During the ordinary angling season for Atlantic salmon and sea trout (1 June-30 August in most rivers), 3439 pink salmon were caught by anglers. During the targeted fishing to remove aquaculture escapees as well as pink salmon, more than 2400 adult pink salmon were caught. In total, 5428 pink salmon were observed in rivers during snorkelling surveys or by video cameras. Further, 497 pink salmon were reported from angling and salmon bag nets and bend nets in the sea.

In 2017, a high number of pink salmon was reported from more than ten rivers per county from Finnmark south to Rogaland (Table 2). In the southernmost part of the country, from Vest-Agder to the Swedish border, fewer pink salmon were reported from 1 to 6 rivers per county. However, it should be noted that 40 pink salmon were caught in Norway's largest river, Glomma, at the south-eastern corner of the country (at $59^{\circ} \mathrm{N}$, Østfold county, Fig. 1). The estuary of Glomma is approximately $2500 \mathrm{~km}$ from the Russian border, measured along the coast.

The unusually large catches of pink salmon in the river Tana in Finnmark County in 2017 mirror the situation in all parts of Norway. As in previous years, Finnmark received the highest number of pink salmon, with a catch of 4121 fish reported from 46 rivers. The largest number of fish was caught in Tana, Komagelva and Vesterelva. During snorkelling surveys in Finnmark in August, a total of 4997 pink salmon were observed in 21 of 22 surveyed rivers. This amounted to $46 \%$ of all salmonid fishes observed during the surveys in these rivers. In many of the rivers draining to the Varangerfjord, there were more pink salmon than other salmonids (R. Muladal, unpublished). Some rivers stand out as pink salmon rivers. In the small river Komagelva (mean annual flow $8.3 \mathrm{~m}^{3} \mathrm{~s}^{-1}$, Fig. 1), $49 \mathrm{~km}$ from the Russian border, 420 pink salmon were caught during the ordinary angling season for Atlantic salmon and the targeted angling for pink salmon, in addition to nearly 2000 pink salmon observed during snorkelling surveys. In the even smaller river Vesterelva (Nesseby municipality, mean annual flow $2.5 \mathrm{~m}^{3} \mathrm{~s}^{-1}$, Fig. 1), $96 \mathrm{~km}$ from the Russian border, 1086 pink salmon were caught, while 638 pink salmon were observed during surveys. The numbers and proportion of pink salmon decreased further west and south from the Varangerfjord. The Varangerfjord rivers apparently contribute to the recruitment to the total stock of pink salmon in the Barents region. 


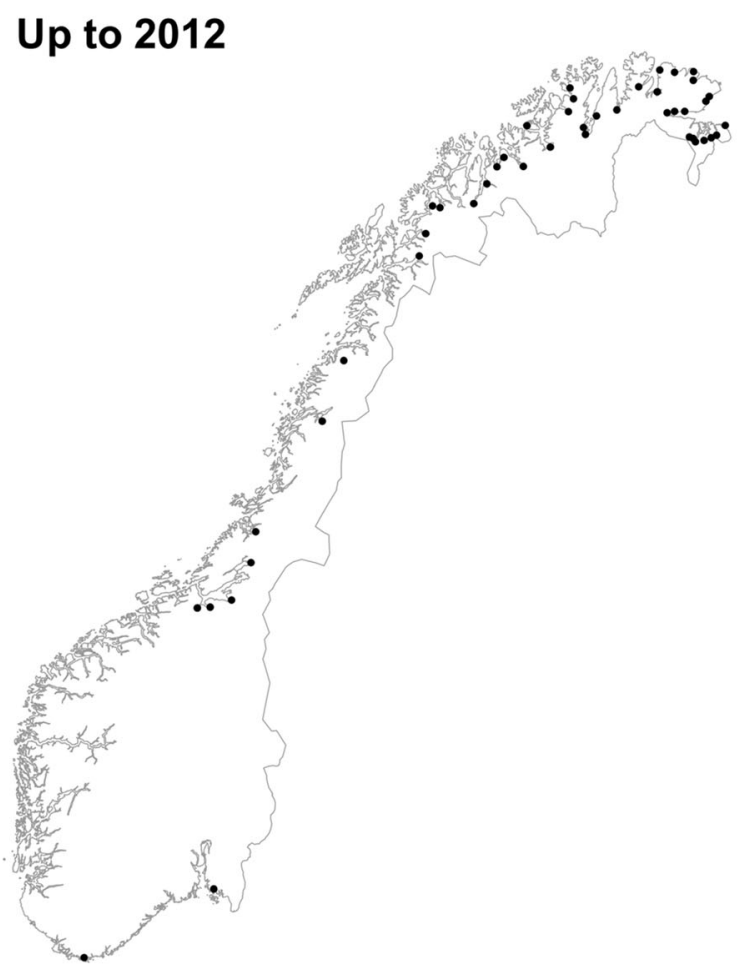

2015

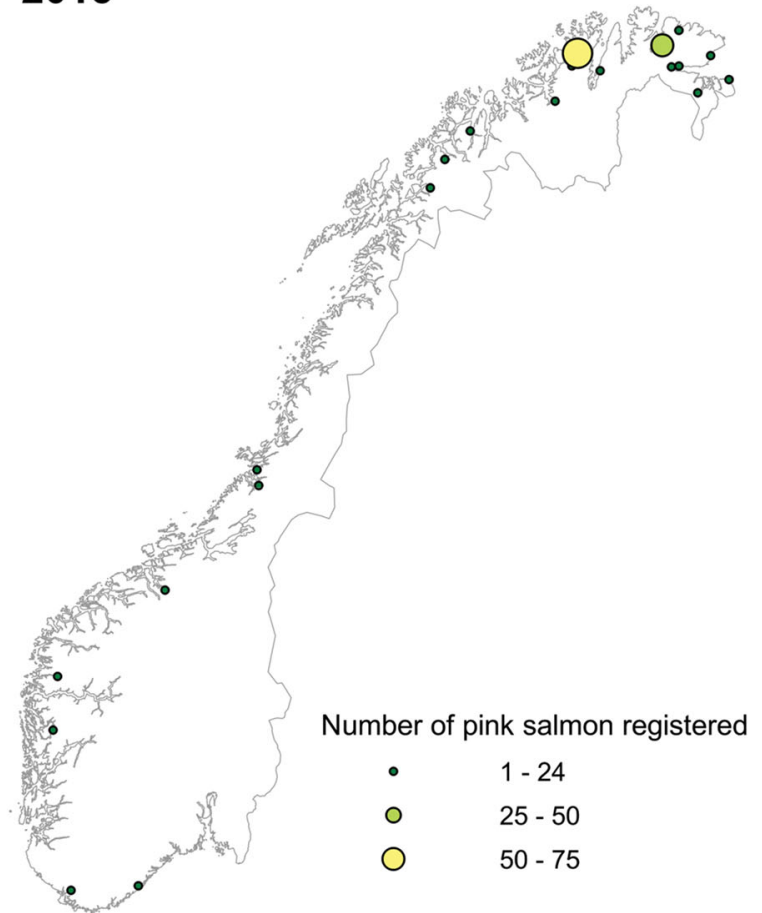

2016
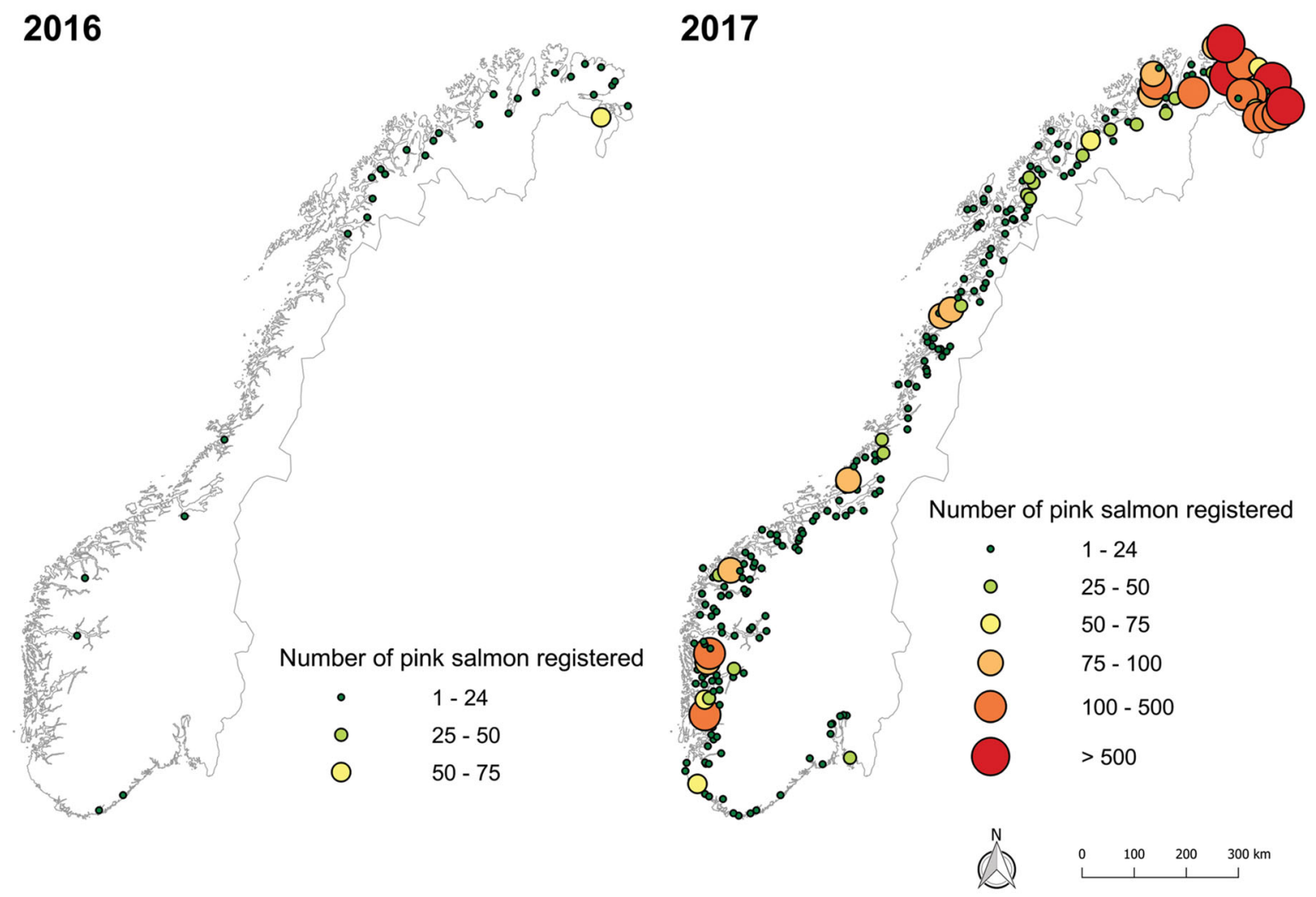
4Fig. 4 Recorded occurrence of pink salmon in Norwegian rivers. Up to 2012: Rivers where pink salmon has been observed or caught before 2012 (Gjelland and Sandlund 2012). 2015, 2016 and 2017: Observations and catches during the last 3 years, including drift counting and video camera monitoring. Note that stocking in Russia stopped in 1999

Several of the rivers in eastern Finnmark with a high number of adult pink salmon, observed spawning and occurrence of pink salmon juveniles, are relatively small (e.g. Vesterelva). This contrasts with observations in the White Sea area, where pink salmon has mainly established populations in medium-sized rivers (mean annual discharge $7-17 \mathrm{~m}^{3} \mathrm{~s}^{-1}$ ), while they appear to avoid spawning in small rivers (mean annual discharge $<3-4 \mathrm{~m}^{3} \mathrm{~s}^{-1}$ ) (A.E. Veselov, unpublished data). During 2017, however, pink salmon entered Norwegian rivers of almost all sizes, from small streams to Norway's largest river, Glomma $\left(705 \mathrm{~m}^{3} \mathrm{~s}^{-1}\right.$ ) (see also Supplementary Table S1).

\section{Arrival time in Norwegian rivers}

The timing of arrival of pink salmon in the river Tana has been recorded for several years through the collection of catch statistics (Niemelä et al. 2016). Over the years 2004-2014, the first fish was caught in the estuary in late May. In the central part of the river ( $>40 \mathrm{~km}$ from the estuary), the first pink salmon was caught around 20 June, indicating that the first arrivals may have remained in the estuary for some weeks. The $50 \%$ cumulative catch was reached around 10 July in both the lower and central river sections, possibly indicating that fish arriving after 20 June move directly into the central river section, given that catches indicate arrival. Catches in the upper section of the river ( $>60 \mathrm{~km}$ upstream) were delayed, with $50 \%$ of the cumulative catch reached in the middle of August (Niemelä et al. 2016).

The high number of rivers with pink salmon catches in 2017 allows a comparison of the first arrival in different parts of Norway. It may appear that the first fish was caught in the rivers around 1 July, regardless of the latitudinal position of the river (Fig. 5a). Exceptions were in the rivers Tana $\left(70^{\circ} 07^{\prime} \mathrm{N}\right)$, Neidenelva $\left(69^{\circ} 42^{\prime} \mathrm{N}\right)$, Sundfjordselva $\left(66^{\circ} 58^{\prime} \mathrm{N}\right)$ and Mandalselva $\left(58^{\circ} 01^{\prime} \mathrm{N}\right)$ where the first pink salmon was caught between 1 and 22 June. The ad hoc manner of information gathering at the beginning of summer may have influenced the early records. The median number of pink salmon was recorded by 10 July in many rivers (Fig. 5b), but in several rivers, both in the north and the south, the median number of fish was recorded as late as the end of August. This timing might be influenced by fishing activities in the rivers, but in any case, there seemed to be no geographic pattern in timing of the catches.

Invader reproduction and establishment

Pink salmon undergo large morphological and physiological changes prior to spawning. The most striking change is the development of a large hump on the back of the males, and the darkening of colour in both sexes (Heard 1991). In photos submitted by anglers, this development was visible in pink salmon caught from mid-July. The spawning sites consist of clean gravel in areas with moderate to fast currents, like the spawning redds preferred by Atlantic salmon and anadromous brown trout. Observations in Norway indicate that pink salmon spawn in the last half of August and beginning of September, which is earlier than the native anadromous salmonids. This is supported by the observation of pink salmon eggs in the gravel underneath eggs of brown trout (T. Wiers, unpublished data).

Spawning of pink salmon was observed in several rivers close to Russia already in 1960, and freeswimming fry were observed in one of these rivers, Bergebyelva, in 1961 (Berg 1977). Spawning fish and subsequent free-swimming or migrating fry occurred in many rivers over the years. For instance, in August 1975, more than 1000 adult pink salmon were observed on the lower $12 \mathrm{~km}$ of the river Neidenelva, and fry migrating downstream were collected in drift traps in late June 1976 (Bjerknes 1977; Bjerknes and Vaag 1980).

Since the turn of the century, spawning pink salmon has been observed regularly in Finnmark. On 1 September 2001, spawning activity was observed in the rivers Karpelva and Neidenelva, and fertilized pink salmon eggs were collected in Karpelva. Observations in the river Vestre Jakobselva in 2007 revealed pink salmon spawning in the period between 10 and 25 August (Muladal 2009). Migrating fry were also observed in Vestre Jakobselva in early 2008 (Niemelä et al. 2016). Observations of fry have also been made 

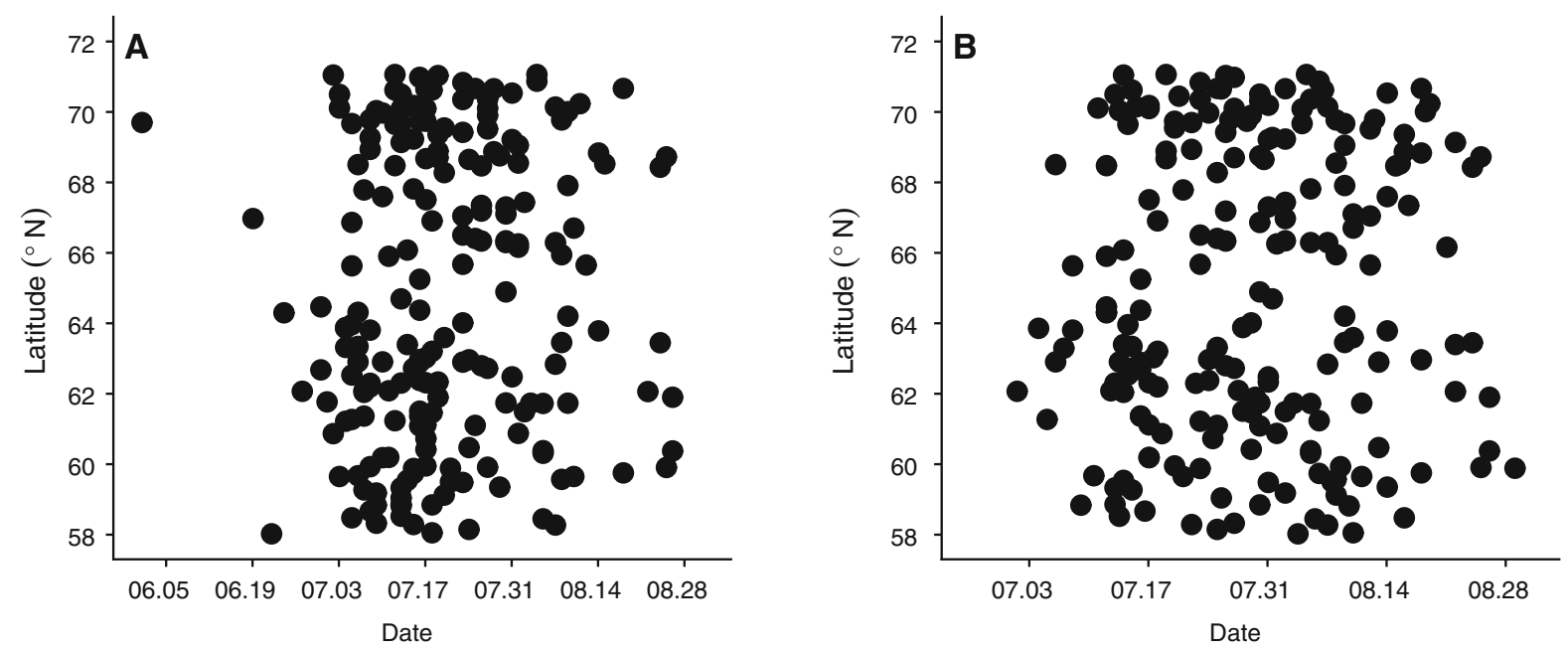

Fig. 5 a The date (MM.DD) of the first catch of pink salmon in 206 rivers according to the geographical (latitudinal) position of the rivers. $\mathbf{b}$ The date when the median number of pink salmon were caught in relation to the geographical (latitudinal) position of 206 rivers

in several Finnmark rivers in recent years (R. Muladal, unpublished data).

The conclusions drawn from recent surveys in Finnmark are that there has been regular reproduction in at least twelve rivers in the eastern part of the county (adjacent to Russia, Fig. 1, Supplementary Table S1) (Niemelä et al. 2016). In the largest Finnmark river, Tana, pink salmon reproduction has not been observed (Niemelä et al. 2016). In the second largest Finnmark river, Altaelva (catchment area $7382 \mathrm{~km}^{2}$, annual mean discharge $99 \mathrm{~m}^{3} \mathrm{~s}^{-1}$ ), which is located further west, only 32 pink salmon were caught even in the peak year 2017. No research has been performed to investigate whether the pink salmon adults ascending these Finnmark rivers originate in Finnmark rivers. One alternative is that the pool of subadult fish in the ocean originate from Russian as well as Norwegian rivers, and that fish returning to any one river might have a mix of origins.

The pink salmon captured in Norwegian rivers in 2017 were mainly mature individuals. Among 272 dissected fish, $43 \%$ were females, while $42 \%$ of 1134 fish sexed based on external characters were females. Among 398 males where maturity stage was recorded, $95 \%$ were mature and $4 \%$ were spent spawners. Among the 357 females, 92\% were mature and $7 \%$ were spent spawners. In both sexes, a few fish were assessed as being immature. Seven females caught between 3 and 27 August had running roe, indicating that they were close to spawning. Spent pink salmon spawners were caught between 8 and 30 August.

Hatching and development into smolt

Pink salmon nests were investigated in a few Norwegian rivers between September 2017 and April 2018. Near Bergen, around $60^{\circ} \mathrm{N}$, the rivers Daleelva, Ekso and Straume were visited repeatedly (T. Wiers, H. Skoglund, K.W. Vollset, unpublished data). Straume is in the brackish water estuary of the river Vosso. In Daleelva, nests excavated in September 2017 were located up to $2.0 \mathrm{~km}$ upstream from the river mouth, and nest gravel depth was $14.9 \pm 3.8 \mathrm{~cm}$. Two batches of eggs collected from this river and brought to a tank at the University of Bergen hatched on two different dates: 5-6 October and then approximately 2 weeks later. Sampling pink salmon nests in the three rivers in January 2018 revealed pink salmon fry of a similar size $(31.3 \pm 0.7 \mathrm{~mm})$ on all locations. While fry in Straume had almost completely resorbed the yolk sac, yolk was still visible in Daleelva and Ekso. In samples collected 26 March and 5 April 2018 pink salmon fry in all three rivers had completely resorbed all their visible yolk sac. These fry were still located $>10 \mathrm{~cm}$ into the gravel, with no apparent tendency to be emerging. On this occasion, new pink salmon nests were also located in Straume and Ekso, in both cases under the nests of anadromous brown trout. 
In the river Jølstra $\left(61^{\circ} \mathrm{N}\right)$, one fry was observed 20 November, 2017. On the same site, approx. $5 \mathrm{~km}$ upstream from the estuary, 15-20 fry were observed in January 2018 (Sigbjørn and Jan-Ove Brede, pers. comm.). The fry were around $30 \mathrm{~mm}$ in length, and in "smolt coloration".

In the river Stordalselva $\left(64^{\circ} \mathrm{N}\right)$, pink salmon fry, approx. $29 \mathrm{~mm}$ in length and with completely resorbed yolk sac, were collected from a gravel depth of approx. $10 \mathrm{~cm}$ on 9 April 2018 (NINA, unpubl. data).

It is known that pink salmon fry start external feeding before migrating downriver as smolts. The preliminary analysis of pink salmon fry stomachs collected in Norwegian rivers in April 2018 confirmed this. Fry from the rivers Ekso and Jølstra had eaten chironomid larvae. Cyclopoid copepods were also present in the fish from Jølstra (unpublished data). In the river Indera on the White Sea shores of the Kola Peninsula, early migrants of pink salmon smolts had mainly fed on zooplankton (copepods), and had only partly resorbed their yolk sac, whereas late migrants had no yolk sac remains, and a full stomach with chironomid pupae and simuliid larvae (Veselov et al. 2016).

In the river Eio $\left(60^{\circ} \mathrm{N}\right)$ on 16 April 2018, pink salmon fry were observed in the river during electrofishing for Atlantic salmon and brown trout smolts. One salmon smolt regurgitated six pink salmon fry while in the keeping tank before tagging, and several smolts of both Salmo species had extended stomachs, indicating that they possibly had consumed a large amount of prey (J.B. Ulvund, INAQ, pers. comm.). Predation on pink salmon eggs by juvenile Atlantic salmon has been documented in Russia (Rasputina et al. 2016).

Observations in Finnmark rivers indicate that the timing of pink salmon fry hatching and migration is variable, both among and within rivers. Bjerknes (1977) caught migrating fry in the river Neidenelva 17-23 June 1976. R. Muladal (unpublished data) caught migrating fry in the river Vestre Jakobselva 16 May 2008. In this case, degree days during incubation was estimated at 450-500. In 2018, pink salmon fry were collected in several Finnmark rivers in the beginning of May (unpublished data).

The migration of pink salmon juveniles has been studied more closely in White Sea rivers (Pavlov et al. 2007, 2009). Commonly, migration occurs shortly after emergence from the gravel at the spawning site, usually in the second half of May. The duration of migration is between 4 and 22 days, with water temperatures rising from 1.5 to $10.5{ }^{\circ} \mathrm{C}$. The juveniles are 25-34 $\mathrm{mm}$ and weigh 200-250 $\mathrm{mg}$ (Zubchenko et al. 2004; Veselov et al. 2016). However, as pink salmon over a period of approximately 20 years have been colonizing spawning sites further upstream, the time spent by juveniles in the river may increase, as demonstrated in the river Indera (Veselov et al. 2016). The spawning sites during the first years in this river were approximately $3.5 \mathrm{~km}$ from the river mouth, whereas in 2014, for the first time, spawning nests were observed 7-12 km from the river mouth. Here, a second group of migrating juveniles were caught in the middle of June 2015. The late migrants were significantly larger (46 vs. $34 \mathrm{~mm}$ ) and heavier (667 vs. $254 \mathrm{mg}$ ). Water temperatures during the late migration were $3.5-10.5^{\circ} \mathrm{C}$. The high growth rates of juvenile pink salmon remaining for a while in freshwater were demonstrated in an Alaskan lake, where the fish increased in length from $32 \mathrm{~mm}$ at emergence to $78 \mathrm{~mm}$ after 3-4 weeks, before descending to the sea (Robins et al. 2005).

\section{Discussion}

\section{Early years}

The first arrival of pink salmon in Norwegian waters in 1960 was a result of the large-scale stockings performed in the White Sea-Kola area in northwest Russia. This supply of adult pink salmon continued while Russian stockings continued until 1979, based on stocking material from Sakhalin. The high numbers of pink salmon ascending Norwegian rivers coincided with high numbers recorded in Russia. Although spawning adults and migrating fry were observed in some Finnmark rivers during this period, it appears that the invasion in Norwegian rivers was maintained by the Russian stocking programme. This conclusion is supported by the fact that no self-reproducing pink salmon were established in Russian rivers during this period (Gordeeva and Salmenkova 2011). Many other translocations of pink salmon have failed in establishing viable populations, e.g. several transfers of pink salmon from the west coast to the east coast of North America (Heard 1991). 
Stocking in northwest Russia was temporary terminated in 1979 and resumed in 1985-1999 with material from the more northerly river Ola in the Magadan area. This resulted in successful establishment in several White Sea rivers (Zubchenko et al. 2018), and probably also in some Finnmark rivers. Abundant invasions in Norway since 1990 have, with very few exceptions, been in odd years, and spawning and downstream migration of fry the following spring has been a common observation.

\section{Ocean migration in the Atlantic}

After the termination of the Russian stocking programme in 1999, with fish returning in 2000, pink salmon is the product of natural reproduction in rivers in northwest Russia and Finnmark draining to the White and Barents Seas. It has been assumed that the stocked pink salmon have utilized the Barents Sea, but the early observation of pink salmon in the Svalbard area (in 1961) as well as catches in Icelandic and British waters may indicate that marine areas further west, in the North Atlantic/Arctic Ocean, may also have been used. It appears likely that, over the generations, naturally produced pink salmon may be utilizing the same areas as Atlantic salmon from rivers in northern Norway and northwestern Russia (Rikardsen et al. 2008; Tonteri et al. 2008; Hedger et al. 2017; Strøm et al. 2018). It does appear that pink salmon is a generalist feeder in the ocean (Radchenko et al. 2018), and it seems likely that the ocean habitat and marine diet of pink salmon to some extent overlap with Atlantic salmon in the Barents Sea and North Atlantic (Nielsen et al. 2013).

The invasion pattern by pink salmon to Norwegian rivers may indicate that the spawners arrive from the northeast, as rivers with the largest numbers and known regular spawning and recruitment are positioned in the northeastern part of the country. This is in line with the observations of pink salmon in Scottish rivers (Armstrong et al. 2018).

In contrast to this, there are observations that may indicate that pink salmon migrants are also approaching from the north or even northwest and west. The observations by Bjerknes and Vaag (1980) indicated that pink salmon first reached the western part of Finnmark, before moving eastwards. They also reported that there appeared to be a second and later wave of migrants reaching the Varangerfjord area from the northeast.

The conclusion is that we have very scant knowledge on the whereabouts of pink salmon in the North Atlantic and the Barents Sea.

\section{Homing versus straying}

The invasion of pink salmon in Norwegian waters after the first stocking in Russia that resulted in returning fish in 1960, indicates a high rate of longdistance straying. The colonization of neighbouring rivers after establishment in the Russian river Varzuga, indicates a straying rate of more than $15 \%$ (A.E. Veselov, unpublished data), but mainly restricted to rivers $10-70 \mathrm{~km}$ away. However, with the number of adult fish in the ocean possibly reaching the millions in some years, a small percentage of straying fish may still appear as a high number of invaders in Norway and elsewhere.

Within the native distribution area in Alaska, Brenner et al. (2012) reported high straying rates by hatchery produced pink salmon. Several authors (e.g., Hendry et al. 2004; Quinn 2005; Ueda 2012) have concluded that pink salmon has a higher rate of straying than other Oncorhynchus species. Still, naturally produced pink salmon may exhibit quite low straying rates $(<10 \%$, Thedinga et al. 2000; Mortensen et al. 2002). According to Putman et al. (2014), ocean migration in pink salmon is mainly associated with geomagnetic imprinting. This is in line with the "compass orientation" during oceanic migration found for tagged pink salmon (Ogura and Ishida 1995). If a migration route based on the Earth's magnetism is imprinted in the smolts and postsmolts of pink salmon on their way out to sea, homing in transplanted populations should be about as good as in natural populations. However, if the fish have inherited knowledge of a map or which compass orientation they should follow, independent of imprinting, one might expect that moving fish from the Pacific Ocean to the White Sea would cause havoc with the homing ability. Even though the data from 2017 indicate a substantial degree of straying, pink salmon born in rivers in northwestern Russia and possibly northern Norway do mainly return to rivers in this region.

Once pink salmon have become established in a river, range expansion in terms of increasing distance 
to upstream spawning sites seem to be fairly quick, as shown by Veselov et al. (2016) in the Russian river Indera. Within the native range of the species, pink salmon also seem to quickly colonize newly available river stretches. In an Alaskan stream made available by a retreating glacier, pink salmon spawners entered the stream 10-12 years after the first invertebrates (chironomid larvae) were observed, and maximum water temperature had reached $8.7^{\circ} \mathrm{C}$ (Milner et al. 2008). In the large Fraser River, removal, after many years, of a migration barrier caused by a landslide, enabled pink salmon to re-establish upstream after one to two generations (2-4 years) (Pess et al. 2012).

On a local scale, the size of the river in terms of freshwater discharge and the distance from the open seas to the river mouth may impact which rivers pink salmon is attracted to. The fact that Norway's largest river, Glomma, which reaches the sea in the outer end of the open Oslofjord, had the highest number of reported pink salmon of all rivers in the eight southernmost counties, may support this. On the other hand, more than 20 pink salmon were caught in the small river Lysakerelva $\left(3.9 \mathrm{~m}^{3} \mathrm{~s}^{-1}\right)$ in the inner end of the Oslofjord, while fewer pink salmon were caught in the much larger river Numedalslågen $\left(111 \mathrm{~m}^{3} \mathrm{~s}^{-1}\right)$ located in the outer Oslofjord.

There are several examples of translocated pink salmon outside of their natural distribution area that has failed. Some were complete failures with no adults returning, while some cases appeared to be successes in the beginning, but with adult fish runs declining and eventually disappearing (Ricker 1972; Neave 1965; Lear 1980). However, a by-product of a failed transfer to Hudson Bay (Ricker and Loftus 1968) was the accidental release of pink salmon into the Great Lakes watershed. This resulted in rapid establishment of healthy populations of pink salmon with a full freshwater life cycle in all the Great Lakes (Kwain and Lawrie 1981; Crawford 2001). Some of the populations have also established a three-year life cycle (Kwain 1987; Kennedy et al. 2005). This indicates that pink salmon has an extensive ability to adapt its life history and ecology to local conditions.

\section{Natural reproduction?}

In several rivers in Finnmark, many adult fish are observed every second year. This may indicate successful propagation. However, we do not have data to prove that spawning in Norwegian rivers produce offspring that survive and return to the same river or to the same region as adults. This would normally be a criterion for deciding that we have established sustained populations. While stocking continued in Russia, and high returns occurred in the same years in the two countries, it is not possible to disregard the possibility that all pink salmon in Norwegian waters could have been the result of Russian stocking.

In Russian rivers it is assumed that production during 1956-1979 was maintained by stocking, except in some occasional years with North Atlantic warming when there might have been natural production of fry (Karpevich et al. 1991). However, when the Russian stocking programme was resumed in 1985 with material from a more northern location, self-reproducing pink salmon was established in the rivers, with subsequent catches varying between 60,000 and 700,000 fish during 1989-2009 (Gordeeva and Salmenkova 2011). They suggested that the inherited behaviour of the southern Sakhalin stocks caused a late arrival to spawning sites in northwest Russia, with subsequent high egg mortality due to an early onset of too low water temperatures during incubation. In contrast, the donor population from the more northerly river Ola would have a behaviour causing earlier spawning, providing a beneficial temperature regime during the embryonic development (Brannon 1987; Khovanskii 2000). It appears likely that the Ola river stock would also be better adapted to the environment in rivers in northern Norway. Although the Finnmark rivers are located further north than the river Ola (approx. $69^{\circ} \mathrm{N}$ and $59^{\circ} \mathrm{N}$, respectively), Finnmark is somewhat warmer than the area where the river Ola is situated. While mean monthly air temperatures in Finnmark are below $0{ }^{\circ} \mathrm{C}$ from November to April, the river Ola area experiences below zero temperatures from October to April (Supplementary Table S2).

While stocking of hatchery fish continued in parallel with natural production (1985-1999), adult pink salmon returning to northwest Russian and west European coasts might have been a mix of these two recruitment processes. Successful fry production of the odd-year broodline might also have occurred regularly in rivers in northern Norway, although observations were scarce.

Without stocking in Russia, the number of pink salmon records have been low in Norwegian rivers, 
except the regular occurrence in Finnmark. In the river Tana, there was a period of above average returns from 1989 to 2007 , followed by very low returns in 2008-2016. The sudden increase of pink salmon in Tana as well as in rivers all over Norway and elsewhere in western Europe in 2017 (Armstrong et al. 2018; Mo et al. 2018), is not easily explained. Without any stocking neither in Russia nor in Norway, it must all be due to natural production. It appears obvious that this cohort must have experienced favourable conditions during all life stages. The reports of pink salmon in northwestern Europe also illustrates the broadcast spreading of adult pink salmon. This may bode for a dramatic expansion of the distribution area of self-reproducing pink salmon populations in the coming years or decades, if spawning, incubation, smolt migration and oceanic life is successful.

\section{Invasion of southern rivers}

In several of the early years with abundant catches of pink salmon in Norway, the occasional observation was made as far south as Bergen $\left(60^{\circ} \mathrm{N}\right)$. However, 2017 was unique in the sense that pink salmon was reported from rivers along the entire coastline. It is interesting to note that, while it is only $49 \mathrm{~km}$ as the fish swims from the border between Russia and Norway (at Grense Jakobselva) to Komagelva, and $96 \mathrm{~km}$ to Vesterelva, it is more than $2500 \mathrm{~km}$ along the coast to the river Glomma in the southeastern corner of Norway, where 40 pink salmon were caught in 2017 (Fig. 1).

It appears that years with warming of the ocean in the North Atlantic and Barents Sea caused spawning and production of fry in Russian rivers when stocking material was taken from the southern populations (Karpevich et al. 1991). This may indicate that physical conditions in the sea, and perhaps also climate as it impacts the water temperature and phenology in the rivers and estuaries, are important factors for the success of pink salmon in the North Atlantic area. In a review of salmon in the Arctic, Nielsen et al. (2013) assumed that increasing temperatures in the ocean as well as in rivers will have a positive effect on pink salmon. In the North Pacific, the increasing pink salmon abundance observed over the recent decades is mainly due to the increasing number of odd-year fish (Irvine et al. 2014), which has been associated with increasing sea temperatures. Climate warming may therefore favour establishment of pink salmon in rivers in the northern part of Norway. We have, however, no information that allows an assessment of how this will influence possible establishment further south along the Norwegian coast, where river temperatures are substantially higher. For example, in Bergen, at approx. $60^{\circ} \mathrm{N}$, no month has mean air temperatures below $0{ }^{\circ} \mathrm{C}$. However, there are some large pink salmon populations in rivers situated in areas where monthly mean air temperatures during winter rarely fall below zero centigrade, e.g. Fraser and other rivers in the State of Washington, USA.

In spite of repeated observations of pink salmon, including the occasional spawning, we have no indications of established self-sustaining pink salmon in Norway south of eastern Finnmark. The chance of successful establishment does, however, increase with the number of spawning attempts, i.e. the number of individual pink salmon entering the rivers. This socalled "propagule pressure" (cf. Simberloff 2009) will remain high, at least in some years, as long as there is successful production in northwest Russia and Finnmark.

Potential impact on native populations and ecosystems

The impact of invasive pink salmon in Norwegian rivers cannot be properly assessed based on present data. The general characteristics of pink salmon ecology in freshwater may indicate limited impact, but the changes observed in other cases of transplanted pink salmon renders limited value to such general assessments. However, in most naturally occurring pink salmon, the fish commonly spawn earlier in late summer and autumn than do Atlantic salmon, anadromous brown trout and Arctic charr. The observations of spawning pink salmon in Norwegian rivers confirm this. However, there may still be interactions between pink salmon and Atlantic salmon on the spawning sites, as they seem to prefer similar spawning habitats. Pink salmon is reported to be aggressive on the spawning sites, which may lead to negative interactions with Atlantic salmon and brown trout. It has been documented that groups of pink salmon may attack Atlantic salmon that are at the spawning sites preparing for spawning. The result is that the Atlantic salmon 
move to river sections less suitable for spawning (Kaliuzin 2003).

The impact of post spawning pink salmon carcasses in the river may work two ways. The rotting fish may cause local oxygen deficiencies, reducing survival of incubating fish eggs in the substratum. On the other hand, the decomposing carcasses may contribute to increased invertebrate production in the river. This could benefit older native salmonid juveniles during late autumn and winter, and possibly also newly hatched fry in the spring (Bailey et al. 2018). In nutrient poor rivers, this may also have other unknown repercussions on the total fluvial ecosystem. Successful spawning and incubation of a high number of pink salmon eggs will result in an increased density of salmonid fry in spring. It is commonly believed that pink salmon fry migrate downriver as soon as the yolk sac is absorbed. Observations in both Russian and Norwegian rivers have modified this, as pink salmon fry were seen to remain for some time after yolk sac resorption, and they had started feeding in the river. Observations in rivers on the west coast in 2017-2018 seem to indicate that pink salmon fry may spend weeks and even months in the river after hatching. Interactions with juveniles of native salmonids depend on how far up the river the pink fry emerges, how long they stay in the river, on their abundance, and on their behaviour. Observations in Russian rivers may indicate that high densities of pink salmon fry may also influence river zoobenthos (Veselov et al. 2016). Competition for space in terms of a safe place to feed and hide may also occur. Pink salmon eggs and fry may also for a short period be a suitable prey for other salmonids in the river (Rasputina et al. 2016, and observations described here).

Translocation of fish species from one area to another may result in the spread of non-native infective organisms, which may cause severe disease and mortality to native fish. A well-documented example in Norway is the introduction of the monogenean Gyrodactylus salaris, which has caused high mortality, mean $86 \%$, of the Atlantic salmon population in many Norwegians rivers (Johnsen and Jensen 1991; Mo 1994). Examination of pink salmon for presence of infective organisms when it was introduced from the Pacific area to northwest Russian rivers seems to be lacking. However, as the introductions included only egg and fry, the number of candidate infections are likely few, mainly vertically transmitted virus, i.e. virus transmitted to the ova from the mother. Several viruses have been observed in farmed and wild salmonids in the Pacific area (Evelyn and Traxler 1978; Kent et al. 1998; Miller et al. 2017; Purcell et al. 2018). Among these, infectious haematopoietic necrosis (IHN) virus and viral haemorrhagic septicaemia (VHS) virus are of concern as they may cause severe diseases in native Atlantic salmonids (e.g. Mulcahy and Wood 1986). Skjåvik (2008) examined 38 and 36 adult pink salmon caught in the Norwegian rivers Tana and Neidenelva, respectively, for the presence of IHN-virus, infectious pancreatic necrosis virus and infectious salmon anaemia virus, but none were found.

The parasite fauna of pink salmon caught in the Russian White Sea river Keret is dominated by food web transmitted trematodes, cestodes and nematodes of marine origin and is like the parasite fauna in adult Atlantic salmon caught in the same area (Niemelä et al. 2016). Based on this parasite fauna similarity, the scientists indicated that pink salmon and Atlantic salmon likely have similar diets during marine feeding (Niemelä et al. 2016). Interestingly, Mo and Poppe (2018) found no cestodes or nematodes in the gut or associated with the internal organs during autopsy of 35 pink salmon caught in the river Glomma in 2017. Species of these two parasite taxa, especially Eubothrium sp. in the gut and Anisakis sp. in the abdominal cavity, are commonly found in adult salmonids caught in Norwegian rivers (Bristow and Berland 1991; Senos et al. 2013, T.A. Mo pers. obs.). The absence of these parasites in pink salmon may indicate a marine diet that differed from the native salmonids.

Zyuganov and Veselov (2015) demonstrated that establishment of pink salmon had a substantial negative effect on the recruitment and abundance of the freshwater pearl mussel (Margaritifera margaritifera) in two rivers in the White Sea basin. This was likely caused by a concurring reduction in density of juvenile Atlantic salmon, which is the obligate host of mussel glochidia larvae in these rivers. Pink salmon fry cannot serve as host for the species-specific glochidia, and even if the mussel larvae were able to attach to pink salmon, the residence time of pink salmon fry in freshwater is too short for the mussel larvae to complete their parasitic stage. 
Future prospects: establishment of new permanent populations

The high numbers of pink salmon in rivers in all parts of Norway in 2017 indicate the high potential for spreading and possible establishment under favourable conditions. The development in the coming years depends on conditions in the rivers and in the ocean, as well as the ability of the species to adapt to new environmental conditions. Under favourable conditions, we may expect high numbers in Norwegian waters in 2019. Under poor conditions, there will be few fish in the coming odd years. However, as long as there are established reproducing populations in northwest Russia and in Finnmark, there is a great risk of new invasions in Norwegian rivers. In other words, there is a permanent, but variable, propagule pressure on rivers in Norway as well as in the rest of northwestern Europe.

The pink salmon presently occurring in northwest Russia and Norway may be better adapted to some regions than others (e.g. eastern Finnmark and Kola/ White Sea area). However, there is no knowledge about these issues. Climate change may also improve possibilities for spreading and establishment in a larger area than observed so far, or a warming climate may act against this presumably cold-water fish species.

Pink salmon's congeneric species rainbow trout is also an alien species in Norway (Hindar et al. 1996). Rainbow trout is reared in millions in net pens along the Norwegian coast (16 million fish in 2016; Forsgren et al. 2018). Escapees from net pens, occasionally in their thousands, constitute a continuous propagule pressure on coastal rivers (Anon. 2011). This has been occurring for many decades, but so far, no selfreproducing populations have been established (Forsgren et al. 2018). Thus, it seems that pink salmon has been more successful than rainbow trout as an invading species.

The impact on the native anadromous salmonids is likely related to the abundance of pink salmon. A high number of aggressive pink salmon on the spawning grounds of native salmonids may cause disrupted or failed spawning by the natives. Furthermore, a high abundance of pink salmon fry feeding in the rivers for a few weeks will most probably depress the availability of space and suitable zoobenthos for other salmonids. In the North Pacific Ocean, it is shown that in years with unusually abundant pink salmon, the food resources are depressed, with a negative impact on other Pacific salmon species, other pelagic fishes and sea birds (Springer et al. 2018; Ruggerone and Irvine 2018).

The repeated observations of spawning, hatching and downstream migration of pink salmon in Norwegian rivers demonstrate that this non-native species can complete the freshwater part of its life cycle. One may speculate that the highest probability of successful establishment of pink salmon in Norwegian rivers south of Finnmark is in moderately sized and large rivers with weak populations of native salmonids. Presently, many Norwegian rivers harbour a low abundance of Atlantic salmon (Anon. 2018). This may increase the chances for establishment of new pink salmon populations. Local climatic conditions, particularly during winter, may also be important. In addition, a high number of pink salmon spawners will produce a high number of smolts, thus increasing the chances for successful return of adults and the establishment of reproducing populations.

The occurrence of pink salmon in rivers will likely be perceived as negative by anglers aiming for the native salmonids. It is a smaller fish than Atlantic salmon and large seatrout, and as the spawning period of pink salmon often will occur within or immediately after the legal angling season in rivers, the pink salmon caught in rivers will be of inferior quality.

This review indicates that we lack knowledge about many aspects of pink salmon as an alien species in Norway. This concerns for instance the origin of pink salmon entering rivers in the autumn, the interactions between adult pink salmon and juvenile and adult native salmonids, the impact of pink salmon fry and smolts in the rivers, and the impact of abundant pink salmon in the sea. Such knowledge is also important for evaluation of the need for mitigation measures, as well as for developing efficient actions to reduce the impact of pink salmon.

Acknowledgements Thanks are due to the anglers in Norwegian rivers fishing for Atlantic salmon and brown trout, for making the effort to report, often including photos, their alien catch when landing pink salmon. We have also been informed about observations of spawning pink salmon, and pink salmon hatchlings and fry/smolts. This has really been an example of citizen science. Information has also been provided by the Norwegian Veterinary Institute, the Institute of Marine Research, and Rådgivende Biologer AS. The assistance from the office of the County Governor of Finnmark is also 
acknowledged, along with the constructive comments by two anonymous reviewers to an earlier version of this paper. Kari Sivertsen and Sigrid Skoglund, NINA, have assisted us with the figures. The collection and synthesis of the information has been funded by the Norwegian Environment Agency (Grant No. 18047030), the Norwegian Research Council (Grant \#243910), and NINA.

Open Access This article is distributed under the terms of the Creative Commons Attribution 4.0 International License (http:// creativecommons.org/licenses/by/4.0/), which permits unrestricted use, distribution, and reproduction in any medium, provided you give appropriate credit to the original author(s) and the source, provide a link to the Creative Commons license, and indicate if changes were made.

\section{References}

Agapov VS (1986) The life cycle of pink salmon Oncorhynchus gorbuscha (Walbaum) acclimatized in the European North of the USSR. Voprosy ikhtiologii 26:779-794 (In Russian)

Althukov YP, Salmenkova EA, Omelchenko VT (2000) Salmonid fishes: population biology, genetics and management. Blackwell Science, Oxford

Anon (1978) Om virksomheten til Direktoratet for vilt og ferskvannsfisk i 1976. St.meld. nr. 55 (1977-78) (In Norwegian)

Anon (2011) Prognoser for lakseinnsig, regnbueørret og klimaendringer: utfordringer for forvaltningen. Temarapport fra Vitenskapelig råd for lakseforvaltning $\mathrm{nr} 2,45 \mathrm{pp}$. https://brage.bibsys.no/xmlui/bitstream/handle/11250/ 2392388/Temarapport2.pdf? sequence $=1 \&$ isAllowed=y (In Norwegian). Accessed 4 Oct 2018

Anon (2018) Status for norske laksebestander i 2018. Rapport fra Vitenskapelig råd for lakseforvaltning $\mathrm{nr} 11,122 \mathrm{pp}$. https://brage.bibsys.no/xmlui/bitstream/handle/11250/ 2503390/Rapport11.pdf?sequence $=1 \&$ isAllowed=y Norwegian). Accessed 4 Oct 2018

Armstrong JD, Bean CW, Wells DA (2018) The Scottish invasion of pink salmon in 2017. J Fish Biol. https://doi. org/10.1111/jfb.13680 (in press)

Azbelev VV (1960) Scientific research works on improvement of efficiency acclimatization of Far Eastern salmons in the White and Barents seas. Nauchno-Tekh Byull Polyarn Nauchno-Issle Proektn Inst Morsk Rybn Khoz Okeanogr (PINRO) 4(14):15-19 (In Russian)

Azbelev VV, Grinyuk IN, Surkova EI et al (1962) The results of natural spawning of the pink salmon in the rivers of Kola Peninsula in 1961. Nauchno-Tekh Byull Polyarn NauchnoIssle Proektn Inst Morsk Rybn Khoz Okeanogr (PINRO) 4(22):24-25 (In Russian)

Bailey CJ, Braun DC, McCubbing D, Reynolds JD, Ward B, Davies TD, Moore JW (2018) The roles of extrinsic and intrinsic factors in the freshwater life-history dynamics of a migratory salmonid. Ecosphere 9(9):e02397. https://doi. org/10.1002/ecs2.2397
Bakshtansky EL (1970) The downstream migration of pink salmon and Siberian salmons, and its delay in the rivers of kola Peninsula, Tr. VNIRO 74:129-143 (In Russian)

Bakshtansky EL (1980) Pink salmon in the Kola Peninsula. In: Thorpe JE (ed) Salmon ranching. Academic Press, New York, pp 245-259

Bartlett G (2017) Pink salmon caught in N.L. likely from Russian stocking program. CBC News. https://www.cbc.ca/ news/canada/newfoundland-labrador/pink-salmonnewfoundland-labrador-russia-1.4297983. Accessed 5 Oct 2018

Basham L, Gilbreath L (1978) Unusual occurrence of pink salmon (Oncorhynchus gorbuscha) in the Snake River of southeastern Washington. Northwest Sci 52:32-34

BBC (2017) Pink Salmon warning after species found in Irish rivers. https://www.bbc.com/news/world-europe40608134. Accessed 4 Oct 2018

Berg M (1961) Pink salmon (Oncorhynchus gorbuscha) in northern Norway in the year 1960. Acta Boreal A Sci $17: 1-24$

Berg M (1977) Pink salmon, Oncorhynchus gorbuscha (Walbaum) in Norway. Report: Institute of Freshwater Research, Drottningholm 56:12-17

Bjerknes V (1977) Evidence of natural production of pink salmon fry (Oncorhynchus gorbuscha Walbaum) in Finnmark, North Norway. Astarte 10:5-7

Bjerknes V, Vaag AB (1980) Migration and capture of pink salmon, Oncorhynchus gorbuscha Walbaum in Finnmark, North Norway. J Fish Biol 16:291-297

Brannon EL (1987) Mechanisms stabilizing salmonid fry emergence timing. Can Spec Publ Fish Aquat Sci 96:120-124

Brenner RE, Moffitt SD, Grant WS (2012) Straying of hatchery salmon in Prince William Sound, Alaska. Environ Biol Fishes 94:179-195. https://doi.org/10.1007/s10641-0129975-7

Bristow GA, Berland B (1991) A report on some metazoan parasites of wild marine salmon (Salmo salar L.) from the west coast of Norway with comments on their interactions with farmed salmon. Aquaculture 98:311-318

Carlson SM, Seamons TR (2008) A review of quantitative genetic components of fitness in salmonids: implications for adaptation to future change. Evol Appl 1:222-238

Chereshnev IA, Volobuev VV, Shestakov AV, Frolov SV (2002) Lososevidnye ryby Severo-Vostaka Rossii (Salmonids of the northeastern Russia). Dal'nauka, Vladivostok (In Russian)

Churikov D, Gharrett AJ (2002) Comparative phylogeography of the two pink salmon broodlines: an analysis based on a mitochondrial DNA genealogy. Mol Ecol 11:1077-1101

Crawford SS (2001) Salmonine introductions to the Laurentian Great Lakes: an historical review and evaluation of ecological effects. Can Spec Publ Fish Aquat Sci 132:1-205

Crawford SS, Muir AM (2008) Global introductions of salmon and trout in the genus Oncorhynchus: 1870-2007. Rev Fish Biol Fish 18:313-344

Dushkina LA (1994) Farming of salmonids in Russia. Aquac Fish Manag 25:121-126

Dyagilev SY, Markevich NB (1979) Different times of maturation of the pink salmon, Oncorhynchus gorbusha, in even and uneven years as the main factor responsible for 
different acclimation results in the northwestern USSR. J Ichthyol 19:30-44

Evelyn TPT, Traxler GS (1978) Viral Erythrocytic Necrosis: natural occurrence in Pacific salmon and experimental transmission. J Fish Res Board Can 35:903-907

Falk-Petersen J, Bøhn T, Sandlund OT (2006) On the numerous concepts in invasion biology. Biol Invasions 8:1409-1424

Fausch KD (2008) A paradox of trout invasions in North America. Biol Invasions 10:685-701

Fiske P, Lund RA, Hansen LP (2006) Relationships between the frequency of farmed Atlantic salmon, Salmo salar L., in wild salmon populations and fish farming activity in Norway, 1989-2004. ICES J Mar Sci 63:1182-1189. https:// doi.org/10.1016/j.icesjms.2006.04.006

Forsgren E, Hesthagen T, Finstad AG, Wienerroither R, Nedreaas K, Bjelland O (2018) Oncorhynchus mykiss; vurdering av $\emptyset$ kologisk risiko. Artsdatabanken/Norwegian Biodiversity Information Centre. https://artsdatabanken. no/fremmedarter/2018/N/28 (in Norwegian). Accessed 6 Oct 2018

Gallagher ZS, Bystriansky JS, Farrell AP, Brauner CJ (2013) A novel pattern of smoltification in the most anadromous salmonid: pink salmon (Oncorhynchus gorbuscha). Can J Fish Aquat Sci 70:349-357. https://doi.org/10.1139/cjfas2012-0390

Gjelland KØ, Sandlund OT (2012) Pukkellaks Oncorhynchus gorbuscha. Norwegian Biodiversity Information Centre, Fact sheet 286 (In Norwegian), 2 pp

Gordeeva NV (2017) The White Sea pink salmon: adaptation, genetics, demography. Studying, rational use and protection of natural resources of the White Sea. In: Conference proceedings. SPb, pp 47-49 (in Russian)

Gordeeva NV, Salmenkova EA (2011) Experimental microevolution: transplantation of pink salmon into the European north. Evol Ecol 25:657-679. https://doi.org/10. 1007/s10682-011-9466-x

Gordeeva NV, Salmenkova EA, Altukhov YuP (2006) Genetic divergence in pink salmon introduced into the European north of Russia: microsatellite and allozyme variation analysis. Russ J Genet 42:268-278

Gordeeva NV, Salmenkova EA, Prusov SV (2015) Variability of biological and population genetic indices in pink salmon, Oncorhynchus gorbuscha transplanted into the White Sea basin. J Ichthyol 55:69-76

Hawkins SL, Varnavskaya NV, Matzak EA, Efremov VV, Guthrie CM III, Wilmot RL, Mayama H, Yamazaki F, Gharrett AJ (2002) Population structure of odd-broodline Asian pink salmon and its contrast to the even-broodline structure. J Fish Biol 60:370-388. https://doi.org/10.1006/ jfbi.2001.1850

Heard WR (1991) Life history of pink salmon (Oncorhynchus gorbuscha). In: Groot C, Margolis L (eds) Pacific salmon life histories. UBC Press, Vancouver, pp 121-123

Hedger RD, Rikardsen AH, Støm JF, Righton DA, Thorstad EB, Næsje TF (2017) Diving behaviour of Atlantic salmon at sea: effects of light regimes and temperature stratification. Mar Ecol Prog Ser 574:127-140

Hendry AP, Castric V, Kinnison MT, Quinn TP (2004) The evolution of philopatry and dispersal: homing versus straying in salmonids. In: Hendry AP, Stearns SC (eds)
Evolution illuminated: salmon and their relatives. Oxford University Press, New York, pp 52-91

Hindar K, Fleming IA, Jonsson N, Breistein J, Sægrov H, Karlsbakk E, Gammelsæter M, Dønnum BO (1996) Rainbow trout in Norway: occurrence, reproduction and establishment, vol 454. NINA Oppdragsmelding. Norwegian Institute for Nature Research, Trondheim

Irvine JR, Fukuwaka M (2011) Pacific salmon abundance trends and climate change. ICES J Mar Sci 68:1122-1130. https:// doi.org/10.1093/icesjms/fsq199

Irvine JR, Michielsens CJG, O'Brien M, White BA, Folkes M (2014) Increasing dominance of odd-year returning pink salmon. Trans Am Fish Soc 143:939-956

Ishida T (1966) Pink salmon in the Far East. In: Salmon in the North Pacific Ocean. Part III. A review of the life history of North Pacific salmon. Int North Pac Ocean Fish Comm Bull 18:29-39

Jensen AJ, Sægrov H, Hansen LP, Fiske P, Gjøsæter H (2013) Rainbow trout and pink salmon in Norway, and their potential threat to Atlantic salmon. ICES WGNAS working paper, No 17-2013: 1-10

Johnsen BO, Jensen AJ (1991) The Gyrodactylus story in Norway. Aquaculture 98:289-302

Kaliuzin SM (2003) Atlantic salmon of the White Sea: problems of reproduction and operation. Petro-Press, Petrozavodsk (In Russian)

Karpevich AF, Agapov VS, Magomedov YM (1991) Acclimatization and cultivation of salmon fish-introduced salmonids. VNIRO, Moscow (In Russian)

Kennedy AJ, Greil RW, Back RC, Sutton TM (2005) Population characteristics and spawning migration dynamics of pink salmon in U.S. water of the St. Marys River. J Great Lakes Res 31:11-21

Kent ML, Traxler GS, Kieser D, Richard J, Dawe SC, Shaw RW, Prosperi-Porta G, Ketcheson J, Evelyn TPT (1998) Survey of salmonid pathogens in ocean-caught fishes in British Columbia, Canada. J Aquat Anim Health 10:211-219

Khovanskii IE (2000) Acclimatization of pink salmon from the northern Sea of Okhotsk in the European North. Ryb Khoz 2:38-39 (In Russian)

Kwain W (1987) Biology of pink salmon in the North American Great Lakes. Am Fish Soc Symp 1:57-65

Kwain W, Lawrie AH (1981) Pink salmon in the Great Lakes. Fisheries 6(2):2-6

Lear WH (1980) The pink salmon transfer experiment in Newfoundland. In: Thorpe JE (ed) Salmon ranching. Academic Press, New York, pp 213-243

Lund RA, Økland F, Hansen LP (1991) Farmed Atlantic salmon (Salmo salar) in fisheries and rivers in Norway. Aquaculture 98:143-150

MacCrimmon HR (1971) World distribution of rainbow trout (Salmo gairdneri). J Fish Res Board Can 28:663-704

MacCrimmon HR, Marshall TL (1968) World distribution of brown trout, Salmo trutta. J Fish Res Board Can 25:2527-2548

Markevich NB, Dyagilev SE, Agapov VS (1978) Formation of local populations of pink salmon in the European North of the USSR (southern coast of the Kola Peninsula). Abstracts. In: Four-party international conference (USSR, 
USA, Canada, Japan), Yuzhno-Sakhalinsk, Oct 1978. Vladivostok, pp 16-18 (in Russian)

McGregor AJ, Lane S, Thomason MA, Zhivotovsky LA, Smoker WW, Gharrett AJ (1998) Migration timing, a life history trait important in the genetic structure of pink salmon. North Pac Anadromous Fish Comm Bull 1:262-273

Miller KM, Li S, Ming T, Kaukinen K, Ginther N, Patterson DA, Trudel M (2017) Survey of infectious agents detected in juvenile Chinook and sockeye salmon from British Columbia and Washington. NPAFCDoc. 1718. Fisheries and Oceans Canada, Pacific Biological Station, Cooperative Resource Management Institute, and St. Andrews Biological Station. http://www.npafc.org. Accessed 25 June 2018

Mills D (1991) Ecology and management of Atlantic salmon. Chapman and Hall, London

Milner AM, Robertson AL, Monaghan KA, Veal AJ, Flory EA (2008) Colonization and development of an Alaskan stream community over 28 years. Front Ecol Environ 6:413-419

Mo TA (1994) Status of Gyrodactylus salaris problems and research in Norway. In: Pike AW, Lewis JW (eds) Parasitic diseases of fish. Samara Publishing Ltd, Cardigan, pp 43-56

Mo TA, Poppe TT (2018) Pukkellaks invaderte norske elver i 2017. Norsk Veterinærtidsskrift 130:243-245 (In Norwegian)

Mo TA, Thorstad EB, Sandlund OT, Berntsen HH, Fiske P, Uglem I (2018) The pink salmon invasion: a Norwegian perspective. J Fish Biol. https://doi.org/10.1111/jfb.13682 (in press)

Moore JW, Gordon J, Carr-Harris C, Gottesfeld AS, Wilson SM, Russell JH (2016) Assessing estuaries as stopover habitats for juvenile Pacific salmon. Mar Ecol Prog Ser 559:201-2015. https://doi.org/10.3354/meps11933

Mortensen DG, Wertheimer AC, Maselko JM, Taylor SG (2002) Survival and straying of Auke Creek, Alaska, pink salmon marked with coded wire tags and thermally induced otolith marks. Trans Am Fish Soc 31:14-26. https://doi.org/10. 1577/1548-8659(2002)131\%3c0014:SASOAC\%3e2.0. $\mathrm{CO} ; 2$

Muladal R (2009) Kartlegging, overvåking og tiltak mot pukkellaks som fremmed art i laksevassdrag i Finnmark. Naturtjenester i Nord. Rapport 3 (in Norwegian)

Muladal R (2011) Kartlegging og overvåking av pukkellaks som fremmed art i nasjonale laksevassdrag (NLV) i Finnmark-2011. Naturtjenester i Nord. Rapport 14 (in Norwegian)

Muladal R (2016) Kartlegging, overvåking, uttak av pukkellaks Oncorhynchus gorbuscha som fremmed art i Finnmark2015. Naturtjenester i Nord. Rapport 2:2016 (in Norwegian)

Mulcahy D, Wood J (1986) A natural epizootic of infectious haematopoietic necrosis in imported Atlantic salmon, Salmo salar L., reared in the enzootic region. J Fish Dis 9:173-175

Neave F (1965) Transplants of pink salmon, vol 830. MS report series (biol.). Fisheries Research Board of Canada, Toronto

Nielsen JL, Ruggerone GT, Zimmerman CE (2013) Adaptive strategies and life history characteristics in a warming climate: salmon in the Arctic? Environ Biol Fishes
96:1187-1226. https://doi.org/10.1007/s10641-012-00826

Niemelä E, Johansen N, Zubchenko AV, Dempson JB, Veselov A, Ieshko EP, Barskaya Yu, Novokhatskaya OV, Shulman BS, Länsman M, Kuusela J, Haantie J, Kylmäaho M, Kivilahti E, Arvola K-M, Kalske T (2016) Pink salmon in the Barents region. Office of the Finnmark County Governor Department of Environmental Affairs. Report 3

Ogura M, Ishida Y (1995) Homing behaviour and vertical movements of four species of Pacific salmon (Oncorhynchus spp.) in the central Bering Sea. Can J Fish Aquat Sci 52:532-540

Olden JD, Lockwood JL, Parr CL (2011) Biological invasions and the homogenization of faunas and floras. Ch. 9. In: Ladle RJ, Whittaker RJ (eds) Conservation biogeography, 1st edn. Blackwell Publishing Ltd, Oxford, pp 224-243

Olsen JB, Seeb LW, Bentzen P, Seeb JE (1998) Genetic interpretation of broad-scale microsatellite polymorphism in odd-year pink salmon. Trans Am Fish Soc 127:535-550. https://doi.org/10.1577/1548-8659(1998)127\%3c0535: GIOBSM\%3e2.0.CO;2

Orell P, Erkinaro J (2007) Snorkelling as a method for assessing spawning stock of Atlantic salmon, Salmo salar. Fish Manag Ecol 14:199-208

Pavlov DS, Lupandin AI, Kostin VV (2007) Mechanisms of downstream migration of the juveniles of river fishes. Nauka, Moscow (In Russian)

Pavlov DS, Nefedova ZA, Veselov AE, Nemova NN, Ruokolainen TR, Vasil'eva OV, Ripatti PO (2009) Age dynamics of lipid status of juveniles of Atlantic salmon (Salmo salar L) from the Varzuga River. J Ichthyol 49:1073-1080

Pejchar L, Mooney HA (2009) Invasive species, ecosystem services and human well-being. Trends Ecol Evol 24:497-504

Pess GR, Hilborn R, Kloehn K, Quinn TP (2012) The influence of population dynamics and environmental conditions on pink salmon (Oncorhynchus gorbuscha) recolonization after barrier removal in the Fraser River, British Columbia, Canada. Can J Fish Aquat Sci 69:970-982

Purcell MK, Powers RL, Evered J, Kerwin J, Meyers TR, Stewart B, Winton JR (2018) Molecular testing of adult Pacific salmon and trout (Oncorhynchus spp.) for several RNA viruses demonstrates widespread distribution of piscine orthoreovirus in Alaska and Washington. J Fish Dis 41:347-355

Putman NF, Jenkins ES, Michielsens CGJ, Noakes DLG (2014) Geomagnetic imprinting predicts spatiotemporal variation in homing migration of pink and sockeye salmon. J R Soc Interface 11:20140542. https://doi.org/10.1098/rsif.2014. 0542

Quinn TP (2005) The behavior and ecology of pacific salmon and trout. American Fisheries Society/University of Washington Press, Seattle

Radchenko VI, Beamish RJ, Heard WR, Temnykh OS (2018) Ocean ecology of pink salmon. In: Beamish RJ (ed) The ocean ecology of Pacific salmon and trout. American Fisheries Society, Bethesda, pp 15-160

Rahel FJ (2002) Homogenization of freshwater faunas. Annu Rev Ecol Syst 33:291-315

Rasmussen B (1961) Stillehavslaks på norskekysten. Fiskeridirektoratets Havforskningsinstitutt, Bergen (In Norwegian) 
Rasputina EN, Shustov YuA, Tyrkin IA (2016) Eggs of pink salmon Oncorhynchus gorbuscha as additional nontraditional food of juvenile Atlantic salmon Salmo salar in rivers of the Kola Peninsula. Russ J Biol Invasions 7:294-296

Ricker WE (1972) Hereditary and environmental factors affecting certain salmonid populations. In: Simon RC, Larkin PA (eds) The stock concept in Pacific salmon. H. R. Macmillan lectures in fisheries. University of British Columbia, Vancouver, pp 19-160

Ricker WE, Loftus KH (1968) Pacific salmon move east. Fisheries Council of Canada. Ann Rev 43:37-39

Rikardsen AH, Hansen LP, Jensen AJ, Vollen T, Finstad B (2008) Do Norwegian Atlantic salmon feed in the northern Barents Sea? Tag recoveries from 70 to $78^{\circ}$ N. J Fish Biol 72:1792-1798. https://doi.org/10.1111/j.1095-8649.2008. 01823.x

Robins JB, Abrey CA, Quinn TP, Rogers DE (2005) Lacustrine growth of juvenile pink salmon, Oncorhynchus gorbuscha, and a comparison with sympatric sockeye salmon, $O$. nerka. J Fish Biol 66:1671-1680

Ruggerone GT, Irvine JR (2018) Numbers and biomass of natural- and hatchery-origin pink salmon, chum salmon, and sockeye salmon in the North Pacific Ocean, 1925-2015. Mar Coast Fish 10:152-168

Ruggerone GT, Nielsen JL (2004) Evidence for competitive dominance of pink salmon (Oncorhynchus gorbuscha) over other salmonids in the North Pacific Ocean. Rev Fish Biol Fish 14:371-390

Scott WB, Crossman EJ (1973) Freshwater Fishes of Canada. Fish Res Board Can Bull 184:1-966

Senos M, Poppe TT, Hansen H, Mo TA (2013) Tissue distribution of Anisakis simplex larvae (Nematoda; Anisakidae) in wild Atlantic salmon, Salmo salar, from the Drammenselva river, south-east Norway. Bull Eur Assoc Fish Pathol 33:111-117

Simberloff D (2009) The role of propagule pressure in biological invasions. Annu Rev Ecol Evol Syst 40:81-102

Simberloff D, Gibbons L (2004) Now you see them, now you don't! - population crashes of established introduced species. Biol Invasions 6:161-172

Skjåvik H (2008) Undersøkelse av pukkellaks (Oncorhynchus gorbuscha) i Finnmark for forekomst av virus. Fordypningsoppgave. Norges Veterinærhøgskole, Oslo (In Norwegian)

Springer AM, van Vliet GB, Bool N, Crowley M, Fullagar P, Lea M-A, Monash R, Price C, Vertigan C, Woehler EJ (2018) Transhemispheric ecosystem disservices of pink salmon in a Pacific Ocean macrosystem. PNAS 115(22):E5038-E5045. https://doi.org/10.1073/pnas. 1720577115

Stankovic D, Crivelli AJ, Snoj A (2015) Rainbow trout in Europe: introduction, naturalization, and impacts. Rev Fish Sci Aquac 23:39-71

Strøm JF, Thorstad EB, Hedger RD, Rikardsen AH (2018) Revealing the full ocean migration of individual Atlantic salmon. Anim Biotelem 6:2
Tarpey CM, Seeb JE, McKinney GJ, Templin WD, Bugaev A, Sato S, Seeb LW (2018) SNP data describe contemporary population structure and diversity in allochronic lineages of pink salmon (Oncorhynchus gorbuscha). Can J Fish Aquat Sci 75:987-997. https://doi.org/10.1139/cjfas-20170023

Thedinga JF, Wertheimer AC, Heintz RA, Maselko JM, Rice SD (2000) Effects of stock, coded-wire tagging, and transplant on straying of pink salmon (Oncorhynchus gorbuscha) in southeastern Alaska. Can J Fish Aquat Sci 57:2076-2085

Tonteri A, Veselov AJ, Zubchenko AV, Lumme J, Primmer CR (2008) Microsatellites reval clear genetic boundaries among Atlantic salmon (Salmo salar) populations from the Barents and White seas, northwest Russia. Can J Fish Aquat Sci 66:717-735. https://doi.org/10.1139/F09-010

Ueda H (2012) Physiological mechanisms of imprinting and homing migration in Pacific salmon Oncorhynchus spp. J Fish Biol 81:543-558. https://doi.org/10.1111/j.10958649.2012.03354.x

Ugedal O, Thorstad EB, Næsje TF, Reinertsen H, Koksvik JI, Saksgård L, Hvidsten NA, Blom HH, Fiske P, Jensen A (2005) Biologiske undersøkelser i Altaelva 2004. NINA Rapport 43. Norwegian Institute for Nature Research, Trondheim (In Norwegian)

Veselov AE, Pavlov DS, Baryshev IA, Efremov DA, Potutkin AG, Ruchiev MA (2016) Polymorphism of smolts of pink salmon Oncorhynchus gorbuscha in the Indera River (Kola Peninsula). J Ichthyol 56:571-576

Whelan K (2017) Pink invaders. Off the Scale, issue 18, SeptOct 2017, pp 14-21. http://www.offthescaleangling.ie/ issue18/offthescale_issue18.pdf. Accessed 5 Oct 2018

Williamson M (1996) Biological invasions. Chapman and Hall, London

Zubchenko AV, Veselov AE, Kalyuzhin S (2004) Pink Salmon (Oncorhynchus gorbuscha): problems in acclimatization in Europe, North Russia. Polar Research Institute of Marine Fisheries and Oceanography (PINRO), Murmansk (In Russian)

Zubchenko AV, Prusov SV, Krylova SS (2010) Status of reserves and management fishing; pink salmon in the White Sea. In: XI All-Russian conference with international participation, 9-11 Nov 2010. Polar Research Institute of Marine Fisheries and Oceanography (PINRO), St. Petersburg, pp 57-58

Zubchenko A, Prusov S, Alekseev M (2018) Main results of the acclimatization of the pink salmon (Oncorhynchus gorbuscha (Walbaum)) in the waters of Northern Russia. Biologicheskie problemy severa. In: Proceedings of the international scientific conference, Magadan, 18-22 Sept 2018 (In press) (In Russian)

Zyuganov VV, Veselov AE (2015) Influence of acclimatization of the Far East pink salmon on degradation of a "Margaritifera margaritifera-Atlantic salmon" ecosystem in the rivers of the basin of the White Sea. Bull Use Prot Nat Resour Russia 6:46-51 (In Russian) 